Increasing temperature and productivity change biomass, trophic pyramids and community-level omega-3 fatty acid content in subarctic lake food webs

\title{
Keva, Ossi
}

2021-01

Keva , O , Taipale , S J , Hayden , B , Thomas , S M , Vesterinen , J , Kankaala , P \& Kahilainen, K K 2021 , ' Increasing temperature and productivity change biomass, trophic pyramids and community-level omega-3 fatty acid content in subarctic lake food webs ' , Global Change Biology , vol. 27 , no. 2 , pp. 282-296 . https://doi.org/10.1111/gcb.15387

http://hdl.handle.net/10138/337432

https://doi.org/10.1111/gcb.15387

acceptedVersion

Downloaded from Helda, University of Helsinki institutional repository.

This is an electronic reprint of the original article.

This reprint may differ from the original in pagination and typographic detail.

Please cite the original version. 
1 Increasing temperature and productivity change biomass, trophic pyramids and community level

2 omega-3 fatty acid content in subarctic lake food webs

3 Ossi Keva $^{\mathrm{a} *}$, Sami J. Taipale ${ }^{\mathrm{a}}$, Brian Hayden ${ }^{\mathrm{b}}$, Stephen M. Thomas ${ }^{\mathrm{c}, \mathrm{d}}$, Jussi Vesterinen ${ }^{\mathrm{e}}$, Paula Kankaala ${ }^{\mathrm{e}}, \mathrm{Kimmo}$

4 K. Kahilainen $\mathrm{f}, \mathrm{g}^{\mathrm{g}}$

$6 \quad$ *Corresponding author and contact details: Keva, O., ossi.keva@jyu.fi, +358400618944

$7 \quad$ Running head: Climate \& land-use effects on subarctic lakes

$9 \quad$ Location and universities:

${ }^{\text {a }}$ Department of Biological and Environmental Science, University of Jyväskylä, P.O. Box 35 (YA), FI-40014, 11 Jyväskylä, Finland.

12 b Biology Department, Canadian Rivers Institute, University of New Brunswick, Fredericton, NB E3B 5A3, 13 Canada.

$14{ }^{c}$ Department of Fish Ecology and Evolution, EAWAG Swiss Federal Institute of Aquatic Science and Technology, Center of Ecology, Evolution and Biogeochemistry, Kastanienbaum, Switzerland

${ }^{d}$ Department of Environmental Systems Science, Crowther Lab, Institute of Integrative Biology, ETH-Zürich,

Zürich, Switzerland

${ }^{\mathrm{e}}$ Department of Environmental and Biological Sciences, University of Eastern Finland, Joensuu, Finland

${ }_{\mathrm{f}}^{\mathrm{f}}$ Lammi Biological Station, University of Helsinki, Lammi, Finland

${ }^{\mathrm{g}}$ Kilpisjärvi Biological Station, University of Helsinki, Kilpisjärvi, Finland 


\section{Abstract}

Climate change in the Arctic is outpacing the global average while land-use is intensifying due to exploitation of previously inaccessible or unprofitable natural resources. A comprehensive understanding of how the joint effects of changing climate and productivity modify lake food web structure, biomass, trophic pyramid shape and abundance of physiologically essential biomolecules (omega-3 fatty acids) in the biotic community is lacking. We conducted a space-for-time study in 20 subarctic lakes spanning a climatic $\left(+3.2^{\circ} \mathrm{C}\right.$ and precipitation: $\left.+30 \%\right)$ and chemical (dissolved organic carbon: $+10 \mathrm{mg} \mathrm{L}^{-1}$, total phosphorus: $+45 \mu \mathrm{g} \mathrm{\textrm {L } ^ { - 1 }}$ and total nitrogen: $+1000 \mu \mathrm{g}$ $\mathrm{L}^{-1}$ ) gradient to test how temperature and productivity jointly affect the structure, biomass and community fatty acid content (eicosapentaenoic acid [EPA] and docosahexaenoic acid [DHA]) of whole food webs. Increasing temperature and productivity shifted lake communities towards dominance of warmer, murky-water adapted taxa, with a general increase in the biomass of primary producers, and secondary and tertiary consumers, while primary invertebrate consumers did not show equally clear trends. This process altered various trophic pyramid structures toward an hour glass shape in the warmest and most productive lakes. Increasing temperature and productivity had negative fatty acid content trends (mg EPA+DHA $\mathrm{g}^{-1}$ dry weight) in primary producers and primary consumers, but not in secondary and tertiary fish consumers. The massive biomass increment of fish led to increasing areal fatty acid content $\left(\mathrm{kg} \mathrm{EPA}+\mathrm{DHA} \mathrm{ha}{ }^{-1}\right)$ towards increasingly warmer, more productive lakes, but there were no significant trends in other trophic levels. Increasing temperature and productivity are shifting subarctic lake communities towards systems characterised by increasing dominance of cyanobacteria and cyprinid fish, although decreasing quality in terms of EPA+DHA content was observed only in phytoplankton, zooplankton and profundal benthos.

\section{Introduction}

Temperature has increased much faster in Arctic regions than the global average, and rate of warming is expected to further accelerate in the future (Cohen et al. 2014). In subarctic Fennoscandia, mean annual air temperature has increased circa $2{ }^{\circ} \mathrm{C}$ since 1850 and temperature and precipitation are further predicted to change by $+2-5^{\circ} \mathrm{C}$ and $+10-30 \%$, respectively, by the end of the $21^{\text {st }}$ century (IPCC 2015: RCP2.6-RCP8.5). Furthermore, precipitation in the region is more likely to fall as rain rather than snow (e.g. Dai and Song 2020). Such climatic shifts will expand catchment vegetation towards higher altitudes and latitudes, promoting overall greening and 
facilitating changing land-use practices. In particular, forestry and agriculture are likely to replace traditional livelihoods such as reindeer herding, subsistence hunting and fishing (Schindler \& Smol 2006; Huntington et al. 2007). Expanding transport networks, settlements, oil drilling and mining activities are rapidly changing the hydrology and productivity of freshwaters (Cott et al. 2015; Denisov et al. 2020; Zubova et al. 2020). Joint effects of changes in climate and land-use in catchment area causes increased leaching of terrestrial dissolved organic carbon, nitrogen and phosphorous, with serious impacts on freshwater species richness, community structure and food web processes (Jeppesen et al. 2012, Nieminen et al. 2015, Hayden et al. 2019, Laske et al. 2019).

Globally, species richness tends to show a decreasing trend from the tropics towards the poles, with this linked to a gradient of decreasing temperature and productivity (for overview see e.g. Gaston 2000, Hillebrand 2004).

The latitudinal gradient in species richness may be linked to multi-trophic level diversity and food chain length due to common underlying drivers of ecosystem size and productivity (Gaston 2000, Takimoto and Post 2013, Baiser et al. 2019). Productivity and ecosystem size are inherently linked, for example large lakes tend to be less productive but provide broader feeding or breeding areas for diverse communities, with subsequent effects on food chain length (Post et al. 2000; Takimoto et al. 2012, Ward and McCann 2017). Food chain length determines the number of trophic levels and thus largely governs the strength of top-down and bottom-up processes. In systems with three or more trophic levels, primary production is suggested to be resource limited (bottom-up regulation), primary consumers top down regulated and secondary consumers resource limited (Hairston et al. 1960, Oksanen et al. 1981, Hansson et al. 2013). Together with bottom-up regulation, top-down predator mediated community-level trophic cascades have been suggested as a factor shaping food web structure driving opposing trends in the biomass of sequential trophic level (i.e. each second trophic level biomass is high; Paine 1980, Carpenter et al. 1985, 2001). These processess govern the shape of trophic (Eltonian) pyramids, which may show different forms from a classic pyramidal shape where energetic loss in each trophic level leads to accumulation of max. circa $10 \%$ of produced biomass to next trophic level, and in certain cases may even show inverted pyramids (Elton 1927, Brown et al. 2004, McCauley et al. 2018). Simple food webs in low diversity and productivity ecosystems may be prone to size-structured populations, trophic cascades and inverted trophic pyramids, but generally there is very little clear evidence of how food web biomass and trophic pyramid shape are influenced by temperature and productivity gradients.

Subarctic regions provide an excellent natural setting to study this phenomenon as they straddle boreal and Arctic biomes, providing clear diversity, climatic and productivity gradients with relatively simple food webs (Hayden 
et al., 2017). Furthermore, the subarctic landscape is scattered with lakes that provide abundant and well defined ecosystems for food web diversity studies (Lau et al. 2020). Increasing temperature and productivity has been shown to shift subarctic lake communities towards more numerous, diverse, smaller-bodied, warmer-water adapted taxa which are more reliant on pelagic energy sources (Hayden et al. 2017, Hayden et al. 2019). However, we do not know how increasing temperature and productivity affects energy transfer efficiency and thus biomass distribution across different trophic levels. Aquatic food webs in many Arctic areas are based on production and transfer of lipids from primary producers to top consumers, where seasonal storage of lipids is important for survival and reproduction of long lived organisms at higher trophic levels (e.g. Jørgensen et al. 1997, Armstrong and Bond 2013). An important subgroup of lipids are polyunsaturated fatty acids (PUFAs), providing essential components for cell development and functioning, however the distribution of lipids and fatty acids varies greately among taxa and trophic levels. While there are several PUFAs, eicosapentaenoic acid (20:5n-3, EPA) and docosahexaenoic acid (22:6n-3, DHA) are considered the most important since they are essential for growth, neural development and reproduction of consumers (Arts et al, 2001, Bou et al. 2017, Yeşilayer and Kaymak 2020). Only certain algae groups, such as dinoflagellates, diatoms and cryptophytes, are able to produce EPA and DHA efficiently and are abundant in cold and nutrient poor lakes (Taipale et al. 2013, 2016). However, warm and eutrophic lake primary producer communities, often dominated with cyanobacteria, are inefficient in EPA and DHA production (Müller-Navarra et al. 2000, 2004, Taipale et al. 2013, 2016). Some species can convert shorter chain fatty acids to EPA and DHA (Geya et al. 2016, Ishikawa et al. 2019), but in many vertebrates this process is considered energetically expensive and thus direct sources from high quality prey are often selected (Twining et al. 2016, Keva et al. 2019). This suggest that at a food web level, differences in primary producer communities induced by temperature and productivity may govern the quality of higher trophic levels (Hixson and Arts 2016, Colombo et al. 2020).

Our main aim in this study was to test how increasing temperature and productivity change structure, biomass and nutritional quality of food web components from primary producers to top consumers using a gradient of Fennoscandian subarctic lakes $(\mathrm{n}=20)$ spanning a climate and land-use gradient. Omega-3 fatty acids, EPA and DHA, were selected as proxies for quality of food web components, since they are physiologically important biomolecules for consumers. First, we hypothesized (H1) that communities shift towards warmer and more murky-water adapted species, with a concurrent increase in food web biomass, and expected that increases in algae and fish biomass along the gradient would have effects on trophic pyramid shape (Jeppesen et al. 2010, 
Hayden et al. 2017, McCauley et al. 2018). Secondly, we hypothesised (H2) that cyanobacteria form an increasing proportion of the phytoplankton communities in warmer and more productive lakes (Przytulska et al. 2017), thus lowering nutritional quality of primary producers. As such, we expected that this difference would be passed through all higher trophic levels (Müller-Navarra et al. 2000, Taipale et al. 2016). Finally, we hypothesized (H3) that increasing temperature and productivity would increase total community biomass including an increase in physiologically important EPA and DHA of the total lake community (Jeppesen et al. 2000, Hayden et al. 2019).

\section{Materials and Methods}

\section{$\underline{2.1 \text { Environmental variables }}$}

We sampled 20 lakes, located in Finnish Lapland across the Tornio-Muoniojoki and Paatsjoki watercourses, spanning northern European climatic (average air temperature in June-September from 1980-2010: 8.4-11.6 ${ }^{\circ} \mathrm{C}$ and precipitation 197-257 $\mathrm{mm} \mathrm{a}^{-1}$ ) and water chemistry (dissolved organic carbon; DOC: $1.9-14.9 \mathrm{mg} \mathrm{L}^{-1}$, total phosphorus; TotP: 3-48 $\mu \mathrm{g} \mathrm{L}^{-1}$ and total nitrogen; TotN: 110-1100 $\mu \mathrm{g} \mathrm{L}^{-1}$ ) gradients (Table S1, Fig. 1). Here, all lakes are considered subarctic and located north of Arctic Circle (AMAP 1998). Climatic differences originate from latitudinal and altitudinal gradients, with temperature and precipitation lowest in northernmost lakes and progressively increasing towards the south. Climatic data were derived from nine Finnish Meteorological Institute weather stations situated within the study region and refer to long-term (1981-2010) average open-water season June-September air temperature and annual precipitation as rain (Hayden et al. 2019). Differences in lake productivity originate predominantly from variation in vegetation and land-use practices within the catchment (Jussila et al. 2014). The northernmost lakes are situated near pristine areas with anthropogenic impacts limited to nature tourism and reindeer herding, and from the timberline southwards industrial forestry activities including large-scale clear-cut areas, site preparation and intensive ditching (Jussila et al. 2014; Hayden et al. 2017; Ahonen et al., 2018, Table S1). Catchment area characteristics and land-use variables were derived with the Finnish Environment Institute VALUE-tool combining catchment and CORINE-database and open map data (Hayden et al. 2017; Ahonen et al. 2018). Lake location (coordinates, altitude), morphometrical data (area, depth, mean depth, volume) and water physical-chemistry (nutrients, light) were derived from the Finnish Environment Institute (HERTTA-database) and National Survey of Finland, or from our own sampling (Table S1). We measured visible light in the water column (LI-COR, A-250, visible light 400-700 nm) at deepest point of lake 
or sampling area (largest lakes) to define $1 \%$ surface light level i.e. compensation depth needed to define proportions of the three major lake habitats littoral, profundal and pelagic (Table S1). Lake trophic states were categorized with TotP concentrations to ultraoligotrophic $\left(0-4 \mu \mathrm{g} \mathrm{L} \mathrm{L}^{-1}, \mathrm{n}=3\right)$, oligotrophic $\left(5-9 \mu \mathrm{g} \mathrm{L} \mathrm{L}^{-1}, \mathrm{n}=7\right)$, mesotrophic (10-29 $\mu \mathrm{g} \mathrm{L}^{-1}, \mathrm{n}=5$ ) and eutrophic ( $\left.\geq 30 \mu \mathrm{g} \mathrm{L}-1, \mathrm{n}=5\right)$ (Fig. 1; Nürnberg 1996). Phytoplankton, pelagic zooplankton, littoral and profundal benthic macroinvertebrates (here after benthos) and fish were sampled in the years 2009-2017. The sampling period was always in late summer (August-September).
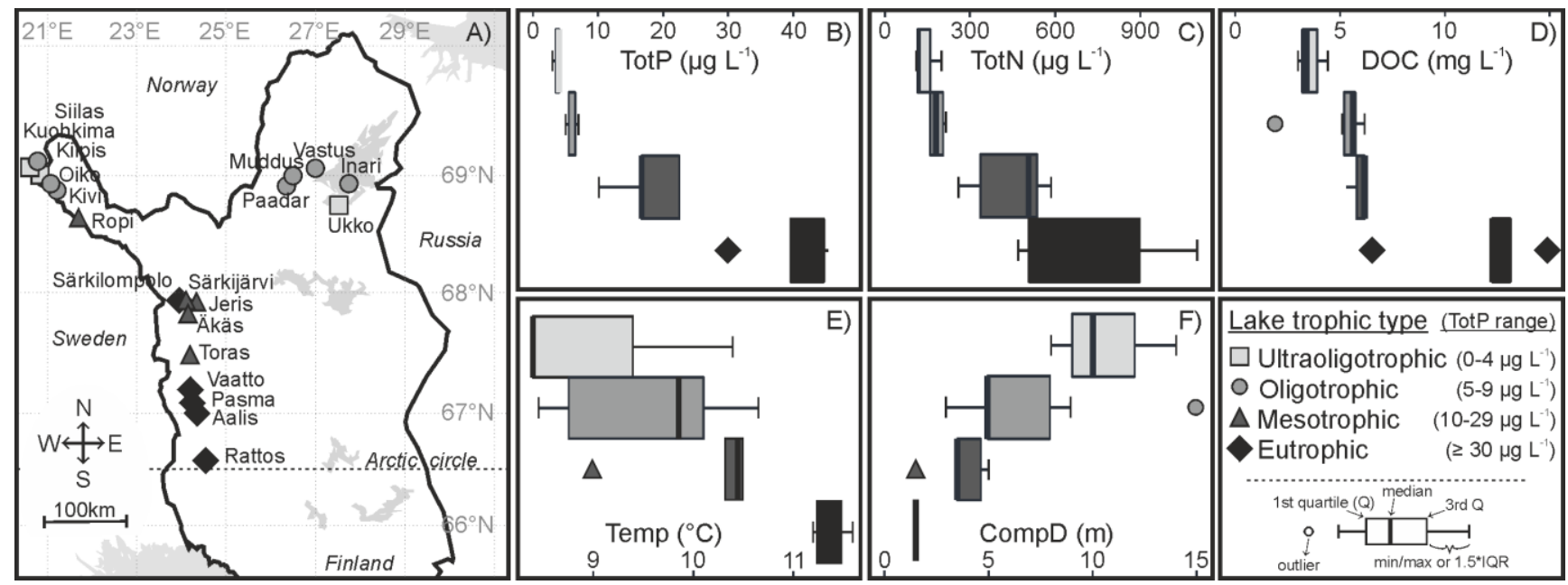

Fig. 1. Map of the study region (A) in northern Fennoscandia and boxplot figures of the basic lake chemistry (B-D) and physics (E-F) of the sampled lakes. The study lakes are marked with grey shade shapes (A) or boxes (B-D) indicating different lake types $($ light grey $=$ ultraoligotrophic, grey $=$ oligotrophic, dark grey $=$ mesotrophic, black $=$ eutrophic $)$. Abbreviations in $\mathrm{x}$-axes labels are named as following: TotP=total phosphorous $(\mathrm{B}), \operatorname{Tot} \mathrm{N}=$ total nitrogen $(\mathrm{C}), \mathrm{DOC}=$ dissolved organic carbon (D), Temp = average air temperature in June-September 1981-2010 (E), CompD = compensation depth i.e. water depth where $1 \%$ surface light is left $(\mathrm{F})$.

\section{$\underline{2.2 \text { Community composition and biomass }}$}

Quantitative phytoplankton taxa samples for eight of the study lakes were extracted from the HERTTA database (Finnish Environment Institute) and from a previous study for an additional six lakes (Taipale et al. 2016). Samples were collected from the epilimnion $(0-2 \mathrm{~m})$ with a Limnos or corresponding water sampler in late summer (August-September), purified using a filter (mesh size: $250 \mu \mathrm{m}$ ) and stored in Lugol solution with added formaldehyde. Phytoplankton cell counts were calculated under a microscope using the Utermöhl technique (Utermöhl 1958). Biomass estimations were done using taxa morphology specific geometric formulas (Hillebrand et al. 1999) and adjusted with experimentally derived carbon-mass ratios (Menden-Deuer and Lessard 2000). Phytoplankton community composition was calculated as class specific percentage from carbon 
biovolume ( $\left.\mathrm{g} \mathrm{C} \mathrm{L}^{-1}\right)$, and dry mass $[\mathrm{dw}]$ per unit area was calculated as well ( $\mathrm{kg} \mathrm{dw} \mathrm{ha}{ }^{-1}$, hereinafter biomass) using lake specific euphotic zone.

Quantitative pelagic zooplankton samples were collected with a net (diameter $25 \mathrm{~cm}$, mesh size $50 \mu \mathrm{m}$ ) using three replicate vertical hauls from the deepest point of each lake (or, in very large lakes, the deepest point of the sampling area) and immediately stored in a 5\% formaldehyde solution (Hayden et al. 2017). We collected pelagic zooplankton for fatty acid analyses from the same point using repeated vertical hauls and these samples were condensed, frozen and freeze-dried in the laboratory. In quantitative samples, all crustaceans were identified to class level, and the body size of 30 first encountered individuals of each class were measured for density and biomass calculations. Biomass was calculated from identified individuals and length measured taxa using sizebiomass (length to dry weight) conversion factors from McCauley (1984). The overall zooplankton community composition was calculated as taxon specific percentage from dry mass biovolume ( $\mathrm{mg} \mathrm{dw} \mathrm{L}^{-1}$ ) and biomass was calculated $\left(\mathrm{kg} \mathrm{dw} \mathrm{ha}^{-1}\right)$ using lake specific average depth.

Benthic macroinvertebrates were collected only from soft bottom with an Ekman grab (area $\left.272 \mathrm{~cm}^{2}\right)$ from a transect (depths 1, 2, 3, 5, 10, 15, 20,30, $40 \mathrm{~m}$ ) spanning from the littoral zone to the deepest point of lake or sampling area. Three separate replicates were taken from each depth and animals were stored in plastic buckets with lake water followed by sorting in laboratory. Animals were identified to lowest feasible level, sorted, counted and total wet biomass of each taxa were weighed (accuracy $0.1 \mathrm{mg}$ ) and areal biomass $\left(\mathrm{g} \mathrm{ww} \mathrm{m}^{-2}\right)$ was calculated for each sample using Ekman area to $\mathrm{m}^{2}$ conversion factor 36.8. For the lake specific biomass calculations, we transformed wet weights to dry weights by using a conversion factor of 0.2 for all taxa (Smit et al. 1993). For each lake, we used water column light level to define compensation depth to define which sampling depths belong to littoral ( $\geq 1 \%$ light) or profundal ( $<1 \%$ light). Then whole lake bathymetry was used to calculate mean benthic macroinvertebrate biomass $\left(\mathrm{kg} \mathrm{dw} \mathrm{ha}^{-1}\right)$ in soft sediments in littoral and profundal regions.

Fish were sampled from three major lake habitats (littoral, profundal and pelagic) using a gill net series composing of eight $30 \mathrm{~m}$ long and $1.8 \mathrm{~m}$ high nets (mesh sizes 12-60 mm knot to knot) and one Nordic net with dimensions of $30 \times 1.5 \mathrm{~m}$ (12 mesh sizes 5-55 mm). A minimum of three gill netting nights per major habitat was conducted and sampling amount was increased proportional to lake area (Malinen et al. 2014; Hayden et al. 2017). Fishing depth of gill nets were verified with echosounder and each fishing period length was recorded with accuracy of a minute. In most cases, gill nets were set overnight in the evening and collected during 
following morning (6-10 hours soaking time), but in the most eutrophic lakes we had to use shorter sampling time ( $<2$ hours) to avoid oversaturation due to a massive increase in fish density in these lakes (Hayden et al. 2017). Fish were immediately killed during net lifting by cerebral concussion and chilled in ice. In the field laboratory, each fish was identified to species level, but whitefish (Coregonus lavaretus) were assigned to the morph (subspecies) level and whitefish $\times$ vendace (Coregonus albula) hybrids were separated based on morphology and colour, as well as head shape and gill raker count (Kahilainen et al. 2011, Kahilainen et al. 2017). This subspecies level delineation was considered essential as many of the northern lakes in the study area are dominated by variable proportions of ecologically contrasting whitefish morphs (2-4 morphs in a lake) that play differential roles in food web structure, energy flows and fatty acid dynamics (Thomas et al. 2017, Thomas et al. 2019).

Total length (accuracy $1 \mathrm{~mm})$ and wet mass $(0.1 \mathrm{~g})$ were measured and the relative abundance of each species was calculated as catch per unit effort (CPUE) i.e. number of individual per species gill net ${ }^{-1}$ hour $^{-1}$. In addition to gill net data, we have previously collected both relative abundance (CPUE) and quantitative estimates of whitefish and vendace density in pelagic habitat (individuals ha ${ }^{-1}$ ) by using vertical echosounding and gill netting from subset of the lakes analysed in the current study (Malinen et al. 2014). We calculated a linear regression equation between CPUE and echosounding derived quantitative density in order to transform relative densities of whitefish and vendace to absolute densities. As one or both of these species are present in all sampled lakes, we used their calculated absolute density and their proportion of total catches to get fish density values for different species in each lake. These density values for each species and their mean individual mass in gill net catch were multiplied to get biomass $\left(\mathrm{kg} \mathrm{ha}^{-1}\right)$. For consistency with other trophic levels, we transformed fish wet weight to dry weight with conversion factor of 0.2 (e.g. Ahlgren et al. 1996). In trophic level analyses, fish were classified as secondary consumers i.e. invertivorous (most species and morphs) and tertiary consumers i.e. piscivorous species (only pike, Esox lucius; burbot, Lota lota, Arctic charr, Salvelinus alpinus; brown trout, Salmo trutta; and $>20 \mathrm{~cm}$ perch Perca fluviatilis) based on previous dietary and stable isotope studies of a subset of the studied lakes (Kahilainen and Lehtonen 2003, Thomas et al. 2017, Hayden et al. 2019).

\section{$\underline{2.3 \text { Lipid extraction and fatty acid analysis }}$}

Homogenized freeze-dried $\left(-50{ }^{\circ} \mathrm{C}\right.$ for $48 \mathrm{~h}$ ) invertebrate and fish dorsal muscle samples were weighed ca. $0.5-$ $1 \mathrm{mg}$ and 3-4 mg respectively to kimax glass test tubes. If material was not limited, duplicate samples were 
analysed. Fatty acids were analysed as methyl esters (e.g. Taipale et al. 2016), identified and quantified using a gas chromatograph attached to mass spectrometer. Samples were spiked with nonadecylic acid (PLFA c19:0). Lipids were extracted with $3 \mathrm{ml}$ of chloroform-methanol solution (2:1 vol) and with sonicator (15 min). Ultrapure water $(0.75 \mathrm{ml}$ of MilliQ) was add to kimax tubes to separate water soluble compounds from lipids. Lipid extract was evaporated and $3 \mathrm{ml}$ of $1 \% \mathrm{H}_{2} \mathrm{SO}_{4}$ add to kimax tube which was incubated in $+50{ }^{\circ} \mathrm{C}$ for $20 \mathrm{~h}$ to produce fatty acid methyl esters (FAMEs). The produced FAMEs were diluted with hexane and analysed using a gas chromatograph attached to a mass spectrometer (GC-2010 Plus and QP-2010 Ultra, Shimadzu, Japan) with Zebron ZB-FAME column $(30 \mathrm{~m}+5 \mathrm{~m}$ guardian $\times 0.25 \mathrm{~mm} \times 0.2 \mu \mathrm{m})$. At the begin of the each GCMS run, the column temperature was held in $50^{\circ} \mathrm{C}$ for $1 \mathrm{~min}$, followed by raising with $10{ }^{\circ} \mathrm{C} \min ^{-1}$ to $130{ }^{\circ} \mathrm{C}, 7^{\circ} \mathrm{C} \min ^{-1}$ to $180{ }^{\circ} \mathrm{C}, 2{ }^{\circ} \mathrm{C} \min ^{-1}$ to $200{ }^{\circ} \mathrm{C}$ and was held there for 3 min which after the colon temperature was raised with 10 ${ }^{\circ} \mathrm{C} \min ^{-1}$ to $260{ }^{\circ} \mathrm{C}$. The injection temperature was $270{ }^{\circ} \mathrm{C}$ and the interface temperature $250{ }^{\circ} \mathrm{C}$, total column flow being $27.5 \mathrm{~mL} \mathrm{~min}^{-1}$ and linear velocity $36.3 \mathrm{~cm} \mathrm{~s}^{-1}$.

Fatty acids were identified based on ion spectrums and quantified based on four-point standard mixture calibration curves (15 ng $\mu \mathrm{L}^{-1}$, $50 \mathrm{ng} \mu \mathrm{L}^{-1}, 100 \mathrm{ng} \mu \mathrm{L}^{-1}$, $250 \mathrm{ng} \mu \mathrm{L}^{-1}$; GLC 566c, Nu-Chek Prep, USA) with GCMS solution software version 4.42 (Shimadzu, Japan). The calibration curves were ran before each run. The coefficient of determination between peak area and standard FA concentrations were always higher than 0.999 . To validate the calibration curves, we run at least one external EPA and DHA standard (Sigma Aldrich CRM47571 \& CRM47570) per batch, average recovery \% \pm RSD of the analysed external standards were 119.2 $\pm 21.4 \%(\mathrm{n}=11)$ and $104.9 \pm 20.5 \%(\mathrm{n}=11)$ for EPA and DHA. The average sum of percent error between sample duplicate $(\mathrm{n}=47)$ FA profiles and EPA+DHA contribution were $2.0 \pm 1.3 \%$ and $0.6 \pm 0.7 \%$, respectively. The mean \pm SD recovery of our internal standard nonadecylic acid in our samples was $90.7 \pm 24.2 \%(n=503)$ and the individual recovery $\%$ was used to adjust the sample FA concentrations. EPA and DHA were the only fatty acids used in the subsequent data analysis.

We combined a small subset of fatty acid data from previous studies having a different focus (Taipale et al. 2016, Vesterinen et al. 2020). Total dataset consisted of 868 samples (Table S2: phytoplankton=32, zooplankton=26, littoral benthos $=209$, profundal benthos $=34$, invertivorous fish=377, piscivorous fish=190). Community specific lake average FA sample coverage of taxa specific biomass contributions stands as following: phytoplankton 93.2 $\pm 5.4 \%$, littoral benthos $59.6 \pm 24.3 \%$, profundal benthos $71.9 \pm 19.9 \%$, invertivorous fish $92.9 \pm 9.0 \%$, 
piscivorous fish $89.7 \pm 23.0 \%$ Table S3. For zooplankton only bulk samples were used in community quality calculations, thus assuming coverage being $100 \%$ (Table S3).

\subsection{Lake specific community EPA + DHA content and areal content calculations}

Computational phytoplankton EPA + DHA content $\left(\mathrm{mg} \mathrm{g}^{-1} \mathrm{C}\right)$ was calculated for study lakes using the class specific carbon mass and their corresponding FA production estimates from laboratory experiments (Taipale et al. 2016). The laboratory-culture experiment derived FA production of phytoplankton taxa might be different from those found in nature, due to varying environmental conditions in natural environments. However, we think this estimation is relevant as microscopy data of phytoplankton community composition and biomass data was available for the study systems. For the consumer communities, EPA + DHA content $\left(\mathrm{mg} \mathrm{g}^{-1} \mathrm{dw}\right)$ was weighed with taxa specific biomass contribution (\%) determined for each lake and taxa, except for zooplankton which was sampled as a whole community. Lake, habitat and taxa specific mean FA content values was used in the community EPA + DHA calculations where possible. If taxa specific fatty acid content was unavailable from a lake, we used measured taxa average FA content from different habitat (for benthos) or same type of lakes (e.g. oligotrophic), with this we supplemented our FA sample coverage near to $100 \%$ for each community (Table S3).

Biomass calculations (in section 2.2.) facilitated the calculation of trophic pyramids, where total food web biomass was divided among trophic levels. Here, we followed above classifications where the first trophic level are primary producers (i.e. phytoplankton), the second is primary consumers (zooplankton and benthic macroinvertebrates), the third is secondary consumers (invertivorous fish), whilst the fourth is tertiary consumers (piscivorous fish). To calculate community EPA + DHA mass per unit area $\left(\mathrm{kg}\right.$ EPA + DHA ha ${ }^{-1}$, herein after: areal content) for primary producers and different consumers, we multiplied community biomass $\left(\mathrm{kg} \mathrm{dw} \mathrm{ha}^{-1}\right)$ and EPA + DHA content. For fish community areal EPA+DHA content we used only muscle tissue of fish instead of whole fish. Furthermore, we used community EPA + DHA areal content $\left(\mathrm{kg} \mathrm{FA} \mathrm{ha}^{-1}\right)$ to calculate trophic pyramids for these assimilated biomolecules through food webs. Our biomass calculations should be considered as minimum estimates, since we did not have any quantitative biomass and FA data from littoral primary producers (periphyton, macrophytes) nor small organisms such as bacteria, rotifers and microbenthos.

\section{$\underline{2.5 \text { Statistical methods }}$}

We calculated a climate-productivity index ( $\mathrm{CPi}$ ) that equals the principal component analysis (PCA) axis one based on lake chemistry (TotP, TotN, DOC), and catchment properties (air temperature, precipitation) to reduce 
the number of environmental variables when testing H1 and H2 (Table S1, Hayden et al. 2019). Here, the PC1 axis (i.e. CPi) explained $81 \%$ of the variation in lake environmental data, and was the only PC used in subsequent analyses (Fig. S1) due to inherent collinearity with land-use practices (Hayden et al. 2019). Within the final derived index, lakes with higher temperature and productivity receive higher CPi values. We built general linear models with forward and backward selection predicting each community biomass with $\mathrm{CPi}$, prey item quality (EPA+DHA content) and predator biomass, where Akaike information criterion (AIC) was used for selection of the best models. To summarize general linear model results, CPi was the main factor affecting community biomass (Table S4-5). Therefore, we used a simple linear regression model to examine the relation between CPi (PC1 scores) and community total biomass (H1) and EPA + DHA areal content (H2). We also used linear regression analysis to test the dependence of community EPA + DHA areal content on lake total biomass (H3). An alpha level of 0.05 was used in each statistical analysis and tests were conducted using R through RStudio version 3.4.1 with the default base package (R Core Team 2017). Figures were drawn using base graphics and ggplot2 package (Wickham 2016).

\section{Results}

\subsection{Changes in community structure, food web biomass and trophic pyramid shape (H1)}

Lake communities showed shifts from cold to warmer adapted taxa with increasing temperature and productivity (Fig. 2). Phytoplankton changed from diatom dominated communities in ultraoligotrophic lakes towards cyanobacteria dominance in eutrophic lakes (Fig. 2 A1). Copepods contributed 50-80\% of the total zooplankton community biomass along this gradient and calanoids had the highest biomass percentage in every lake type. However, copepod contribution was lowest in eutrophic lakes where cladocerans, especially Bosmina had a high biomass percentage (Fig. 2 A2). Littoral benthos communities were diverse throughout the lake gradient (Fig. 2 A3): Asellus sp. and Lymnaea sp. reached the highest proportional contribution in mesotrophic lakes, whereas oligochaetes had the highest biomass contribution in ultraoligotrophic lakes and lowest in eutrophic lakes. Profundal benthos was mainly dominated by chironomids and their biomass contribution increased from ultraoligotrophic lakes (ca. 50\%) towards eutrophic lakes (ca. 90\%) (Fig. 2 A4). Invertivorous fish communities were dominated by salmonids (whitefish, vendace) in ultraoligotrophic lakes; by percids (perch and ruffe, Gymnocephalus cernuus) and salmonids in oligotrophic-mesotrophic lakes; and by cyprinids (roach Rutilus 
rutilus, bleak Alburnus alburnus) in eutrophic lakes (Fig. 2 A5). Piscivorous pike and perch increased their biomass contribution progressively from ultraoligotrophic lakes (ca. 35\% and 5\%) towards eutrophic lakes (ca. $50 \%$ for both species), whilst piscivorous Arctic charr and brown trout disappeared completely along the same gradient (Fig. 2 A6).

Phytoplankton mean mass increased more than twenty-fold between ultraoligotrophic $(0.08 \pm 0.05$; mean $\pm \mathrm{SD} g$ $\mathrm{dw} \mathrm{m}^{-3}$ ) and eutrophic lakes $1.9 \pm 0.8 \mathrm{~g} \mathrm{dw} \mathrm{m}^{-3}$ (Fig. $2 \mathrm{~B} 1$ ), which was also evident for biomass along our lake gradient CPi (PC1) from north to south based on linear regression analysis (Fig. 3 A1). The lowest zooplankton biomass was observed in mesotrophic lakes $\left(9.27 \pm 5.96 \mathrm{mg} \mathrm{dw} \mathrm{m}^{-3}\right)$ (Fig. $\left.2 \mathrm{~B} 2\right)$, however no clear trend in biomass was observed along the lake gradient (CPi) based on linear regression (Fig. 3 A2). The overall highest littoral benthos biomass was observed in mesotrophic lakes (Fig. 2 B3), but no clear trend in biomass along the continuous CPi axis (Fig. $3 \mathrm{~A} 3)$. The profundal benthos biomass was low in ultraoligotrophic lakes $(0.4 \pm 0.3 \mathrm{~kg}$ $\left.\mathrm{dw} \mathrm{ha}^{-1}\right)$ and increased towards eutrophic lakes $\left(8.2 \pm 11.3 \mathrm{~kg} \mathrm{dw} \mathrm{ha}^{-1}\right)$. This trend was mainly caused by increasing chironomid biomass (Fig. 2 B4) and driven mainly by extremely high profundal benthos densities in two lakes with low oxygen (Fig. 3 A4). Generally invertivorous fish biomass was circa five times higher in eutrophic lakes $\left(69.7 \pm 49.0 \mathrm{~kg} \mathrm{dw} \mathrm{ha}^{-1}\right)$ compared to other lake types (pooled average: $15.8 \pm 12.9 \mathrm{~kg} \mathrm{dw} \mathrm{ha}^{-1}$ ) (Fig. 2 B5; Fig. 3 A5). The biomass of piscivorous fish was around four times higher in eutrophic lakes (15.9 \pm $7.8 \mathrm{~kg} \mathrm{dw} \mathrm{ha}^{-1}$ ) than other lake types (pooled average: $4.2 \pm 3.2 \mathrm{~kg} \mathrm{dw} \mathrm{ha}^{-1}$ ). (Fig. $2 \mathrm{~B} 6$ ), and a clear linear trend along the $\mathrm{CPi}$ axis was observed (Fig. 3 A6). These massive increases in primary producer and secondary consumer biomass compared primary and tertiary consumers were evident in changes to the trophic pyramid shape (Fig. 4, Fig. S2). Ultraoligotrophic and oligotrophic lakes showed variable shapes from typical pyramids to inverted pyramids to across different lakes, whilst most mesotrophic lakes were generally typical pyramids and eutrophic lakes had hour glass shaped biomass distributions (Fig. 4, Fig. S2). 

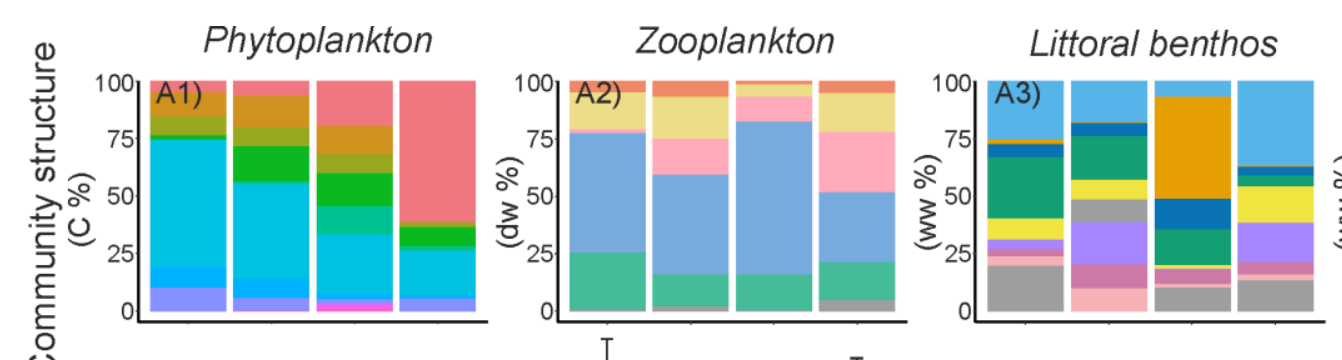

Profundal benthos

Invertivorous fish

Piscivorous fish
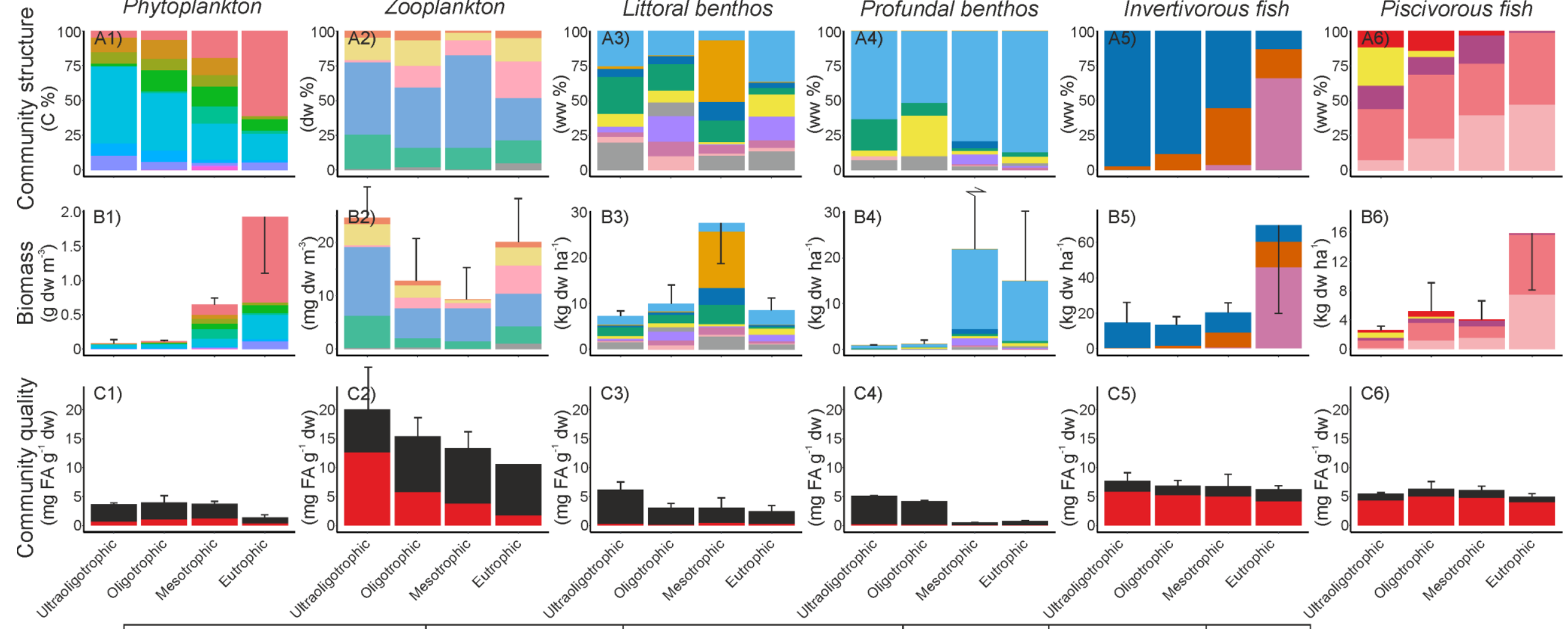

\begin{tabular}{|ll|l}
\hline Key for A1, B1 & Key for A2, B2 \\
$\square$ Cyanophyceae & $\square$ Diatomophyceae & $\square$ Holopedium sp. \\
$\square$ Cryptophyceae & $\square$ Charophyceae & $\square$ Daphnia sp. \\
$\square$ Dinophyceae & $\square$ Chlorophyceae & $\square$ Bosmina sp. \\
$\square$ Chrysophyceae & $\square$ Raphidophyceae & $\square$ Calanoida \\
$\square$ Synurophyceae & $\square$ Euglenophyceae & $\square$ Cyclopoida
\end{tabular}

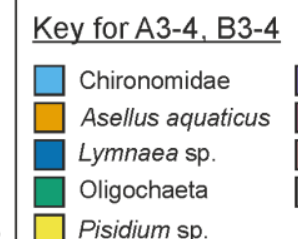

\begin{tabular}{l|}
$\square$ Sialis sp. \\
$\square$ Trichoptera \\
$\square$ Valvata sp. \\
$\square$ Others
\end{tabular}
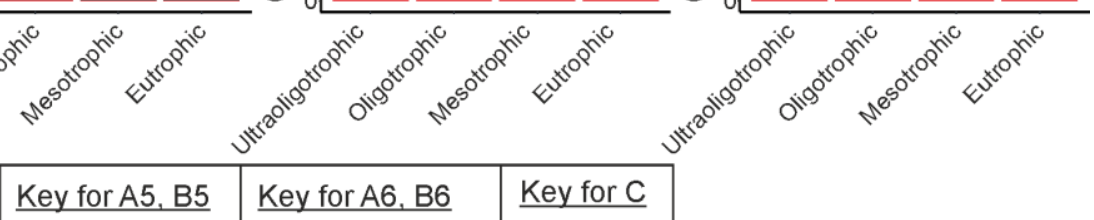

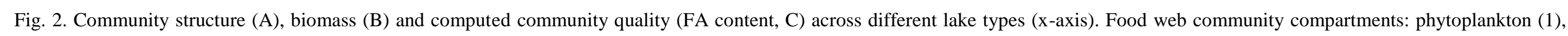

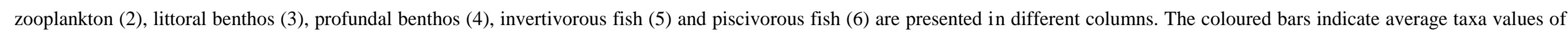

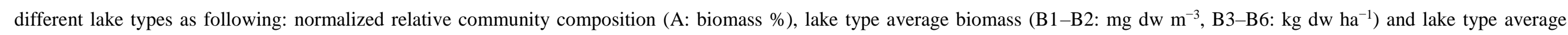

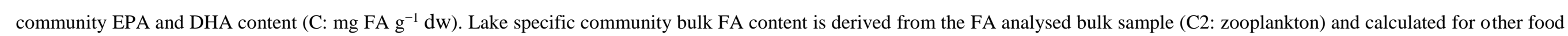

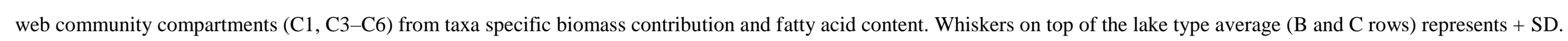




\subsection{Changes in fatty acid content of food web components $(\mathrm{H} 2)$}

Phytoplankton quality (EPA + DHA) was highest in oligotrophic and mesotrophic lakes, and clearly the lowest in eutrophic lakes (Table S6, Fig. 2 C1). Zooplankton quality was the highest in ultraoligotrophic lakes (20.1 \pm $8.9 \mathrm{mg} \mathrm{g}^{-1} \mathrm{dw}$; mean $\pm \mathrm{SD}$ ) and progressively decreased towards eutrophic lakes (10.6 $\mathrm{mg} \mathrm{g}^{-1} \mathrm{dw}$ ) (Fig. $2 \mathrm{C} 2$ ), but due to high variance and low sample size the EPA + DHA distributions did not differ statistically among the lake types (Table S6). Benthos quality was limited to the presence of EPA. Littoral and profundal benthos quality were the highest in ultraoligotrophic lakes and the lowest in eutrophic lakes (Table S6, Fig. 2 C3-4). There was no statistically significant differences in quality of invertivorous and piscivorous communities between lake types as EPA+DHA content remained stable (Table S6, Fig. 2 C5-6). EPA and DHA content of primary producers and consumers decreased along the $\mathrm{CPi}$ axis, but there was no statistically significant trend in secondary or tertiary consumers (Fig. 3 B1-6, Fig. S3).

\section{$\underline{3.3 \text { Changes in community EPA + DHA areal content }(\mathrm{H} 3)}$}

The highest values of community EPA + DHA areal content came from invertivorous fish (pooled average \pm SD: $\left.0.188 \pm 0.214 \mathrm{~kg} \mathrm{ha}^{-1}\right)$, followed by piscivorous fish $\left(0.050 \pm 0.054 \mathrm{~kg} \mathrm{ha}^{-1}\right)$, phytoplankton $(0.036 \pm 0.030 \mathrm{~kg}$ $\left.\mathrm{ha}^{-1}\right)$, littoral benthos $\left(0.023 \pm 0.019 \mathrm{~kg} \mathrm{ha}^{-1}\right)$, pelagic zooplankton $\left(0.015 \pm 0.026 \mathrm{~kg} \mathrm{ha}^{-1}\right)$ and profundal benthos $\left(0.007 \pm 0.017 \mathrm{~kg} \mathrm{ha}^{-1}\right)$, respectively. Trends in EPA + DHA areal content of phytoplankton, zooplankton, and benthos communities with total food web biomass were not significant (Fig. 3C1-4), though showing generally opposing patterns between trophic levels: EPA + DHA areal content of phytoplankton community was smallest in oligotrophic lakes but remained relatively stable in meso- and eutrophic lakes, whilst invertebrate taxa showed the opposite pattern. The areal contents of EPA + DHA of invertivorous (adj. $\mathrm{r}^{2}=0.86$ ) and piscivorous (adj. $\mathrm{r}^{2}=0.45$ ) fish communities were positively related to total biomass of food web (Fig. 3C 5-6, Table S7). Community EPA + DHA areal content showed a similar pattern as total biomass along the studied lake gradient, emphasizing the fundamental link between total community biomass and EPA + DHA areal content (Fig. 3A, C, Table S7). 

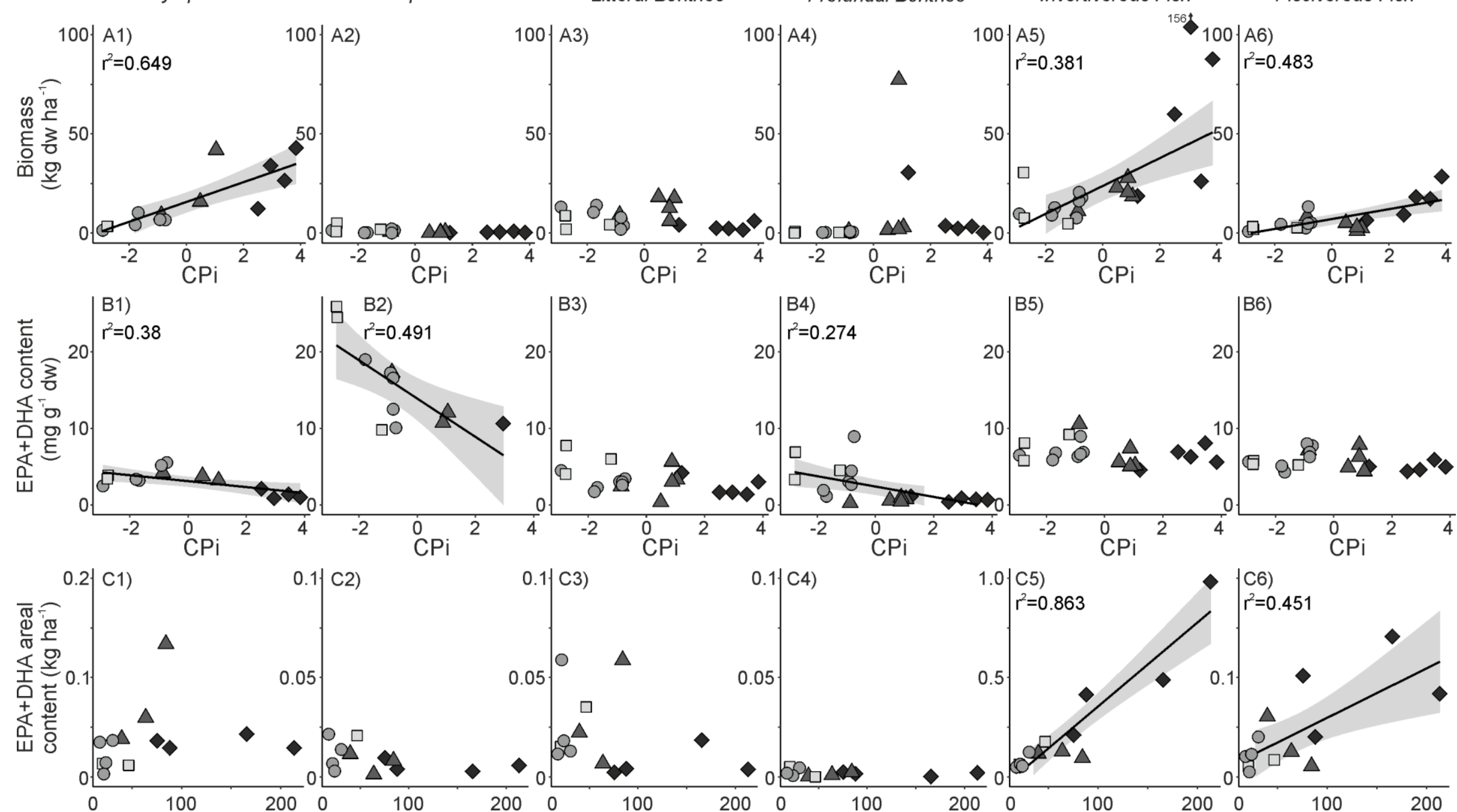

Total foodweb

Total foodweb

Total foodweb

Total foodweb biomass ( $\left.\mathrm{kg} \mathrm{ha}^{-1}\right)$ biomass (kg ha-1) biomass $\left(\mathrm{kg} \mathrm{ha}^{-1}\right)$ biomass $\left(\mathrm{kg} \mathrm{ha}^{-1}\right)$

Total foodweb biomass ( $\mathrm{kg} \mathrm{ha}^{-1}$ )

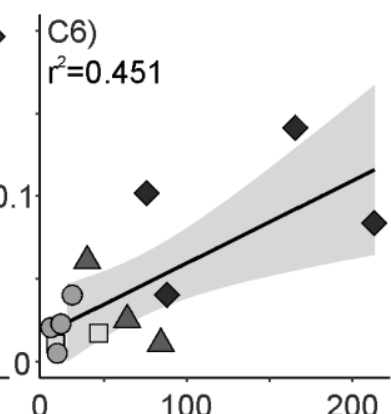

Total foodweb biomass ( $\left.\mathrm{kg} \mathrm{ha}^{-1}\right)$ 
Fig. 3. Linear regression models showing A-B: Community biomass $\left(\mathrm{kg} \mathrm{dw} \mathrm{ha}^{-1}\right)$ and quality $\left(\mathrm{mg} E P A+D H A ~ g^{-1} \mathrm{dw}\right)$ against climate-productivity index $(\mathrm{CPi})$ and $\mathrm{C}$ : EPA + DHA areal content $\left(\mathrm{kg}\right.$ EPA+DHA ha $\left.{ }^{-1}\right)$ against total food web biomass ( $\mathrm{kg} \mathrm{dw} \mathrm{ha}{ }^{-1}$ ). Food web community compartments: phytoplankton (1), zooplankton (2), littoral benthos (3), profundal benthos (4), invertivorous fish (5) and piscivorous fish (6) are presented in different columns. The grey shaded shapes indicate different lake trophy corresponding to Fig. 1: light grey square $=$ ultraoligotrophic, grey dot $=$ oligotrophic, dark grey triangle $=$ mesotrophic, black diamond $=$ eutrophic. Linear regressions fits $($ bolded line), $95 \%$ confidence limit (grey shaded areas) and adjusted coefficient of determination $\left(\mathrm{r}^{2}\right)$ are presented in the figures if the model was statistically significant $(\mathrm{p}<0.05)$. Linear regression equations, F statistics, adjusted $\mathrm{r}^{2}$ and $\mathrm{p}$ values are presented for each model in Table S6.

\section{Discussion}

\subsection{Major trends}

Based on our findings, we suggest that increasing temperature and productivity fundamentally alter the structure and function of subarctic lake communities. Here, warmer, more nutrient rich waters promote communities with an increasing share of blue-green algae, smaller-bodied zooplankton, smaller benthic macroinvertebrate taxa and warmer water adapted cyprinid fishes. Moreover, we observed clear positive trends in biomass in each second trophic level (i.e. phytoplankton and invertivorous fish), which increased along the lake gradient. Deviating trends in contrasting trophic levels had subsequent effects on shaping trophic pyramids, where only eutrophic lakes seems to settle into a common hour glass shape. The omega-3 content (mg EPA $\left.+\mathrm{DHA} \mathrm{g}^{-1} \mathrm{dw}\right)$ of primary producers and consumers decreased along the climate-productivity gradient, but these trends were not observed in longer living secondary and tertiary consumers (i.e. fishes). Increasing total biomass of food webs along the climate-productivity gradient increased community EPA + DHA areal content, with this especially visible in invertivorous and piscivorous fish communities.

\section{$\underline{4.1 \text { Changes in community structure, biomass and trophic pyramids (H1) }}$}

Across our study lake gradient — from northern ultraoligotrophic lakes to eutrophic lakes — food webs shifted towards dominance of warmer and murky water adapted species. These changes were the clearest in primary producers, where communities moved from diatom dominance to cyanobacteria, and secondary consumers, where salmonids were replaced by cyprinids. While many of our biomass calculations follow the relative density results, obtained in a previous study conducted along a partially overlapping gradient (Hayden et al. 2017), there were clear differences in biomass trends among trophic levels. Here, primary producers and secondary consumer 
biomass increased most dramatically from cold ultraoligotrophic lakes towards warm eutrophic systems, but there were no clear trends in primary consumers and biomass increment of tertiary consumers was shallower. Past food web level studies have found similar patterns, whereby phytoplankton and invertivorous fish biomass tend to respond most strongly to increasing nutrient concentrations (Hanson and Leggett 1982, Jeppesen et al. 2000, Carpenter et al. 2001). Moreover, joint effects of increasing temperature and productivity boost food web level change where oligotrophic subarctic lakes are mainly fuelled by benthic algae, but gradually shift towards phytoplankton derived energy sources towards warmer and more productive lakes (Vadeboncoeur et al. 2003, Hayden et al. 2019). As key drivers of the biomass increment in our data set for primary producers are cyanobacteria and for secondary consumers cyprinid fish those are both adapted to warm waters (Kosten et al. 2012, Rolls et al. 2017). Both are competitively superior in warmer and productive environment as many cyanobacterial taxa can fix nitrogen directly from air and form dense colonies to avoid predation, whilst cyprinids across the region have omnivorous diets and very high fecundity (Kosten et al. 2012; Winfield and Nelson 1991, Lappalainen et al. 2008). Such uneven changes in community structure and biomass in different trophic levels were critical in shaping food webs and trophic pyramids.

Biomass patterns across trophic levels showed contrasting trends in response to increasing temperature and productivity. This corroborates the "Green World Hypothesis", where primary producers (phytoplankton) are bottom-up controlled by nutrients, and primary consumers (zooplankton and benthos) are top-down controlled by invertivorous fish (Hairston et al. 1960). However, this model is a simplification of complex aquatic food webs such as the study lakes, as all additionally contain tertiary consumers (e.g. Arctic charr, pike; although their relative biomass and proportional contribution to trophic pyramids was variable). Whilst top consumers biomass increment was shallower compared to invertivorous fish biomass with increasing temperature and productivity, the most diverse piscivore communities colonizing all lake habitats inhabited coldest and most nutrient poor lakes only. Previous work from these cold and clear lakes suggest a strong top-down role of piscivorous fish on invertivorous fish density and biomass (Jensen et al. 2015, Thomas et al. 2017, Kahilainen et al. 2019). These cold and nutrient poor lakes have generally low biodiversity that promotes both highly size structured fish populations, i.e. strong year class dominance for 10-15 years, and potential for strong trophic cascades (Byström 2006, Hayden et al. 2014a, Kahilainen et al. 2019). This likely explains the diverse shape of trophic pyramids we observed, especially in ultra-oligotrophic and oligotrophic lakes. Increasing temperature and nutrients are fundamental controls that decrease piscivore top-down control and boost bottom-up processes, whereas trophic 
pyramids seem to stabilize into a hourglass shape in eutrophic lakes. Such trophic pyramid shape is obviously very persistent as common biomanipulation efforts of mass removal of invertivorous consumers (e.g. roach) tend to quickly return to original state (Carpenter et al. 1985, Hansson et al. 1998). Therefore, it is likely that especially in eutrophic lakes the piscivore predation on invertivorous fish is not limiting their population size, as observed elsewhere (e.g. Bartrons et al. 2020). Nutrient concentration is well-known driver of alternative stable states of lakes (Scheffer and Carpenter 2003) and underlying mechanisms maintaining resilience of eutrophic state may include a hourglass shape of trophic pyramid driven by proportionally high biomass of primary producers and secondary consumers (Jeppesen et al. 2010). Yet, the nutrient level and reason for the possible tipping point of the lake food web communities should be further evaluated in future.
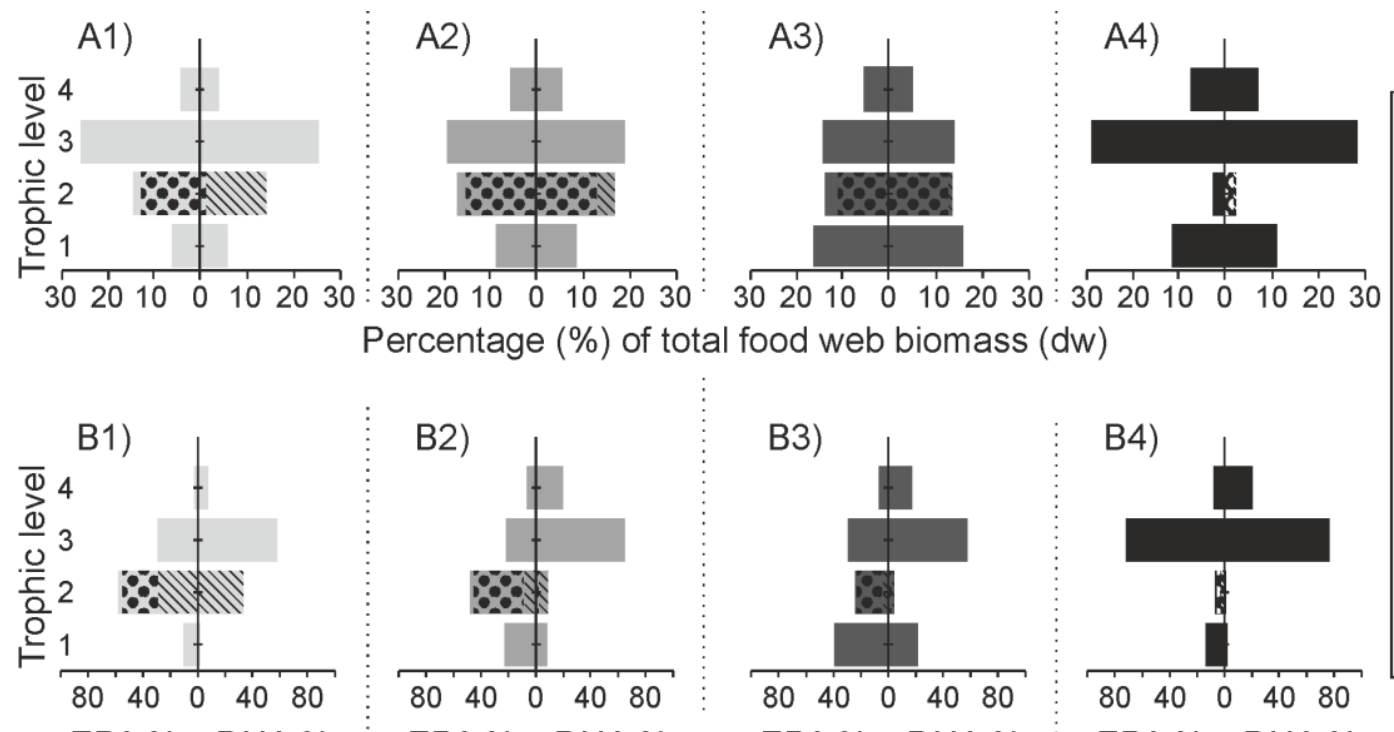

Percentage (\%) of total food web biomass (dw)

EPA \% DHA \%
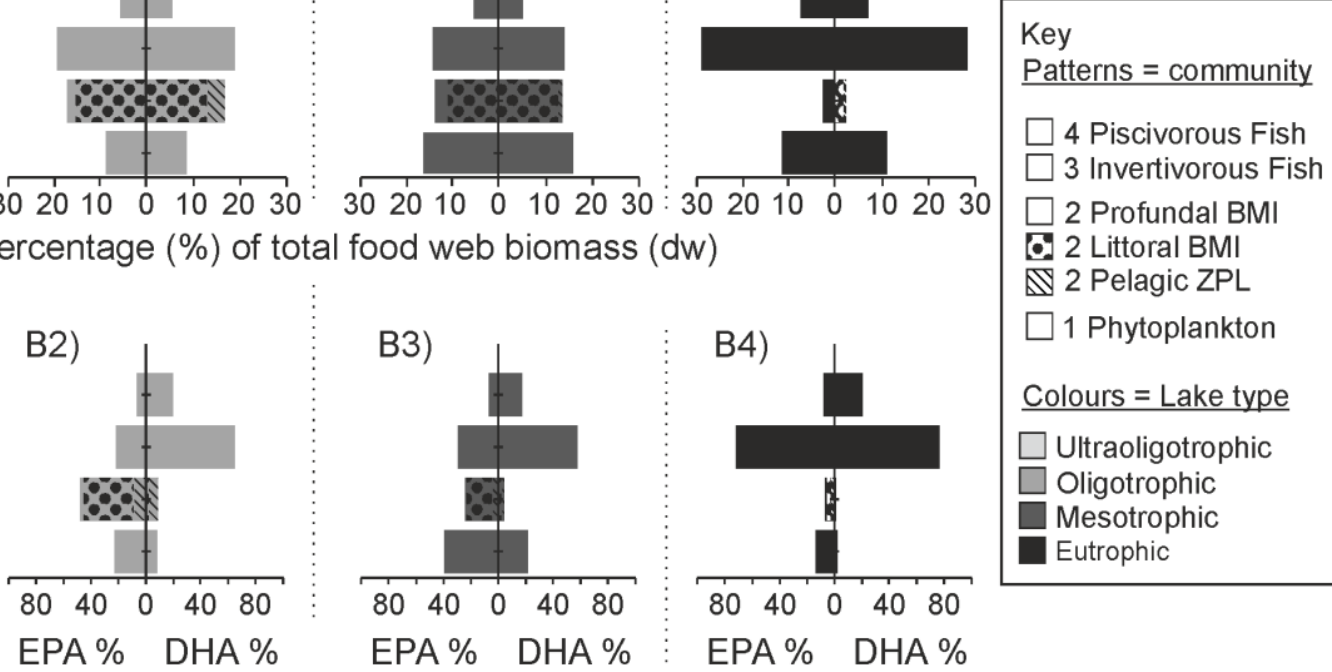

Percentage (\%) of total food web EPA and DHA mass

Fig. 4. Relative biomass (A) and FA stock (B) pyramids by food web compartments for the lake types. The pyramid steps represent lake type averages of relative biomass or EPA+DHA areal content and are ordered with trophic level from bottomup order: 1) phytoplankton, 2) invertebrates, 3) invertivorous fish and 4) piscivorous fish. The second trophic level (invertebrates) are divided among profundal benthos, littoral benthos and zooplankton with patterns: transparent, spots, stripes respectively. Different lake types, ultraoligotrophic, oligotrophic, mesotrophic and eutrophic respectively, are separated into different columns delineated with dashed lines and additionally with light grey, grey, dark grey, black respectively. The lake specific data is presented at Fig. S2. Abbreviations in legend are BMI = benthic macroinvertebrates and ZPL = zooplankton. 


\subsection{Changes in EPA+DHA content of food web components $(\mathrm{H} 2)$}

The nutritional quality ( $\mu \mathrm{g}$ EPA + DHA $\mathrm{mg}^{-1} \mathrm{dw}$ ) of primary producers and consumers with short lifecycles (i.e invertebrates) showed a decreasing trend towards warmer and more productive lakes, while in secondary and tertiary vertebrate consumers (i.e. fishes) such trends in nutritional quality were not apparent. Along the environmental gradient, the phytoplankton community shifted towards more cyanobacteria-dominated communities, which are non-EPA and non-DHA synthesizing phytoplankton (e.g. Taipale et al. 2016). The decrease in zooplankton EPA + DHA content varied with an increasing abundance of small cladoceran and cyclopoid copepods. There are many differences in life history strategies between different zooplankton taxa, where the calanoid Eudiaptomus graciloides, the dominant copepod in cold oligotrophic lakes, tends to accumulate lipids (including FAs) to survive winter, whereas short-lived cladocerans form resting stages and do not need high body fat reserves (Hiltunen et al. 2016, Grosbois et al. 2017). In a recent study, Senar et al. (2019) investigated a similar nutrient (total phosphorus 6-48 $\mu \mathrm{g} \mathrm{L}^{-1}$ ) and colour (dissolved organic carbon 2-10 $\mathrm{mg} \mathrm{L}^{-1}$ ) gradient in Canadian lakes, but did not record clear decrease in zooplankton taxa FA content. However, their study region was warmer and did not contain strong temperature gradients, which have clear influence on lipid rich copepod abundance in zooplankton communities and thus PUFA content (Gladyshev et al. 2011, Hiltunen et al. 2016, Senar et al. 2019).

Decreasing nutritional quality ( $\mu \mathrm{g}$ EPA + DHA $\mathrm{mg}^{-1} \mathrm{dw}$ ) in primary producers was predicted to result in similar trends in secondary and tertiary consumers (Ahlgren et al. 1996, Taipale et al. 2016). However, we did not find this to be the case and instead the EPA + DHA content of fish population was generally stable, in contrast to our second hypothesis. This could be related to diversity in lipid metabolism of different fish species during different development stages, since our study included many fish species at different developmental stages. A range of aquaculture and experimental studies indicate that EPA and DHA supplement increase fish individual growth and to some extent the muscle FA content of adult fish (Bou et al. 2017, Yeşilayer and Kaymak 2020). However, similar evidence from the wild is very difficult to obtain due to limited food resources, slow growth rate of fish, long turnover time of muscle tissue, reproduction cycle, and species-specific differences in lipid storages (Jørgensen et al. 1997, Thomas and Crowther 2015, Keva et al. 2019). One alternative for stable fish EPA + DHA content could be that the ability for conversion of DHA from ALA varies greatly among fish species and development stage (Geay et al. 2016, Kabeya et al. 2018, Ishikawa et al. 2019). Since, benthic macroinvertebrates included only a minor amount of DHA as reported also previously, zooplankton is clearly the most likely dietary 
source of DHA for fish (e.g. Makhutova et al. 2016; Vesterinen et al. 2020). The EPA + DHA content of fish muscle did not differ among feeding habitats (zooplanktivore, benthivore, piscivore), possibly providing evidence for selective transfer or utilization of FAs in fish (Strandberg et al. 2015). Previous results from subarctic lakes indicated that the turnover rate of whitefish (Coregonus lavaretus) muscle is slow, and thus stable isotope ratios and fatty acid content responded very slowly to any diet change (Thomas and Crowther 2015, Hayden et al. 2014a, Keva et al. 2019, Thomas et al. 2019). Our results did not support the idea that prey quality is essential to supporting fish consumer biomass or quality. Together, these results suggest that lipid metabolism is variable and complex among different fish species and their life stages, where generalization of temperature and productivity induced responses to fatty acid content and even further to consumer biomass require more laboratory and field work with wild fish populations.

\section{$\underline{4.3}$ Changes in community EPA + DHA areal content $(\mathrm{H} 3)$}

The climate-productivity gradient of subarctic study lakes included both eutrophication and browning processes from cold and clear water lakes toward warm and murky waters (Hayden et al. 2019). While the EPA + DHA content of primary producers and consumers did show a clear decrease as suggested by earlier studies (Taipale et al. 2016, Creed et al. 2018), the EPA + DHA areal content at a systemic level did not show corresponding decrease due to massive increase of total biomass; similar patterns have previously been observed in mesocosm studies of benthic communities (Scharnweber et al. 2020). Surprisingly, EPA + DHA areal content in secondary and tertiary consumers indeed increased towards more murky lakes, indicating that total biomass clearly overrode the decline of quality. Changes in phytoplankton EPA + DHA areal content were highest in more eutrophic lakes, even if cyanobacteria contribution to this would be bypassed highlighting the importance of biomass to community EPA + DHA areal content and potentially to production as well. The total areal FA content does not exhibit a 1:1 relationship with the production of phytoplankton due taxa specific production rates (Taipale et al. 2020). However, even with a far lower areal content to production ratio in eutrophic lakes, the system level production of EPA + DHA would still be higher in more eutrophic lakes due to massive phytoplankton biomass increment from oligotrophic towards eutrophic lakes. Therefore, we argue that in the studied climate and productivity gradient the total production of fatty acids are higher in warm murky than cold and clear water lakes. 


\subsection{Caveats}

While our sampling protocol did not cover all the food web components, our results from sampled organisms are in general comparable to previous studies conducted from subarctic or boreal lakes. The biomass estimates of fish consumers were derived from simultaneously collected echosounding and gill net CPUE data of pelagic whitefish and vendace, which were collected from a subset of the same study lakes during optimal sampling window using standardized protocols suitable for these two species inhabiting all lakes in current study (Malinen et al. 2014). Our total fish biomass estimates of from ultra-oligotrophic to mesotrophic lakes corroborates well with biomass estimates derived from subarctic Canada (Samarasin et al. 2015). In addition, results from our eutrophic lakes correspond to biomass estimates derived from mark-recapture, population analysis and echosounding methods of boreal eutrophic lakes (Olin et al. 2017, Rask et al. 2020). The comparison of biomass results of primary producers and primary consumer values to earlier studies from boreal lakes (Leppä et al. 2003, Nurminen et al. 2018) indicate broadly similar estimates, but clearly lower values than hypereutrophic and warmer lakes (Jeppesen et al. 2000, Gyllström et al. 2005). Future studies should include biomass estimates of benthic algae as they are very important sources of energy in oligotrophic subarctic lakes (Vadeboncouer et al. 2003, Hayden et al. 2019), but could be important in other types of lakes too (Vesterinen et al. 2016, Vadeboncouer and Power 2017). Assuming a high benthic-to-pelagic production ratio (70\%) in our ultraoligotrophic lakes and low ratio (0\%) in shallow eutrophic lakes (Vadeboncoeur et al. 2008) the increment in primary producer biomass among the lake gradient would be less pronounced and this would affect also the biomass pyramids. However, whole food web primary production is known to increase along phosphorous gradients (Vadeboncoeur et al. 2003) and the biomass pyramids are more persistent to the changes in one trophic level biomass share due to multiple trophic levels accounting the total biomass. To make future fatty acid budget and production calculations more accurate we suggest analysing whole fish or creating species specific conversion factors from muscle tissue to whole body.

\subsection{Conclusions}

While climate warming trends have been evident in the last decades in Finnish Lapland (Hayden et al. 2014b), increases in lake productivity via catchment greening and especially encroachment of the treeline will likely take much longer to become apparent. Historically, the treeline of Scots pine has been located in the highest latitude lakes of our study with circa $2.5^{\circ} \mathrm{C}$ higher July air temperatures, indicating the potential for alteration of catchment vegetation and lake productivity towards north (Kultti et al. 2006). While the lake productivity shifts 
apparent in our study systems originate from intensive forestry activities, there is increasing evidence of resource use related land-use in subarctic focusing on oil and gas drilling, and mining, as well as their associated infrastructure such as roads, pipelines and tailing ponds; activities that are simultaneously changing catchments and lake ecosystems with climate (e.g. Schindler \& Smol 2006; Cott et al. 2015, Denisov et al. 2020). Under current study settings, we show that increasing temperature and productivity have major impacts on lake ecosystems, shifting communities towards warm and murky water adapted taxa, where especially biomass of cyanobacteria and cyprinid fish are increasing. These have a major effect on lake food webs, where increasing biomass of primary producers and secondary consumers shift trophic pyramid shapes towards a persistent hourglass shape. Based on our findings, increasing temperature and productivity did reduce phytoplankton, zooplankton and profundal benthos community EPA + DHA content, but these changes in prey quality did not alter fish community EPA + DHA content. Instead, fish community areal EPA+DHA content did increase along the gradient due to a massive increment in fish biomass. While we are not proposing direct predictions of near future food web structure and quality, our results from a pronounced climate and productivity gradient clearly showed that warmer and murkier water adapted species will likely increase their biomass share, whereas a decrement in EPA+DHA content may only be observed in primary producers and consumers.

\section{Acknowledgements}

We thank all who contributed their help in the field and laboratory over the data collection period. Kilpisjärvi Biological Station, Muddusjärvi Research Station, Muonio County Fish Facility, and Nuottavaara Village Association provided excellent field lab facilities. Funding was received from Academy of Finland (projects 1140903, 1268566 to KKK and 310450 to PK) European Regional Development Fund (A30205 to KKK), Ministry of Agriculture and Forestry (KKK), Emil Aaltonen Foundation (KKK), University of Jyväskylä graduate fund (OK). All authors declare no conflict of interest. At all stages of this study, national guidelines (FI564/2013 \& FI-487/2013) and the European Union directive (2010/63/EU) on the protection of animals used for scientific purposes were applied.

\section{$\underline{\text { Author contributions }}$}

KKK provided the original idea for the paper. KKK, SJT and OK contributed planning the manuscript. Field work was conducted mainly by KKK, SMT and BH. Fatty acid extraction and analysis was performed mostly by 
OK, with contributions from SJT, SMT, JV, PK. OK compiled data, conducted statistical analyses and drafted the first version of the manuscript. All authors contributed to subsequent revisions of the manuscript.

542

\section{$\underline{\text { Author ORCIDs }}$}

Ossi Keva: 0000-0002-5381-3879, Sami J. Taipale: 0000-0001-7510-7337, Brian Hayden: 0000-0002-85247373, Stephen M. Thomas: 0000-0001-5125-691X, Jussi Vesterinen: 0000-0003-3126-2698, Paula Kankaala: 0000-0002-1422-2806, Kimmo K. Kahilainen: 0000-0002-1539-014X

\section{Data sharing and data accessibility}

Supplementary data including 7 tables and 3 figures related to this article can be found at Global Change Biology web page [type URL here]. More data that support the findings of this study are available from the corresponding author upon reasonable request.6. References

Ahlgren, G., Sonesten, L., Boberg, M., Gustafsson, I.B., (1996). Fatty acid content of some freshwater fish in lakes of different trophic levels-a bottom-up effect? Ecology of Freshwater Fish 5: 15-27. https://doi.org/10.1111/j.1600-0633.1996.tb00033.x

Ahonen, S.A., Hayden, B., Leppänen, J.J., Kahilainen, K.K. (2018). Climate and productivity affect total mercury concentration and bioaccumulation rate of fish along spatial gradient of subarctic lakes. Science of the Total Environment 637-638: 1586-1596. https://doi.org/10.1016/j.scitotenv.2018.04.436

AMAP (1998). AMAP Assessment Report: Arctic Pollution Issues. Arctic Monitoring and Assessment Programme (AMAP), Oslo, Norway.

Armstrong, J.B., Bond, M.H. (2013). Phenotype flexibility in wild fish: Dolly Varden regulate assimilative capacity to capitalize on annual pulsed subsidies. Journal of Animal Ecology 86: 966-985. https://doi.org/10.1111/1365-2656.12066

Arts, M.T., Ackmann, R.G., Holub, B.J. (2001). "Essential fatty acids" in aquatic ecosystems: a crucial link between diet and human health and evolution. Canadian Journal of Fisheries and Aquatic Sciences 58: 122-137. https://doi.org/10.1139/cjfas-58-1-122 
564 Baiser, B., Gravel, D., Citwill, A., Dunne, J., Fahimipour, A., Gilarranz, L.J., ... , Yakel, J. (2019). 565 Ecogeographical rules and the macroecology of food webs. Global Ecology and Biogeography 28: 1204-1218. https://doi.org/10.1111/geb.12925

Bartrons, M., Mehner, T., Argillier, C., Beklioglu, M., Blabolil, P., Hesthagen, T., ..., Brucet, S. (2020). Energybased top-down and bottom-up relationships between fish community energy demand or production and phytoplankton across lakes at a continental scale. Limnology and Oceanography 65: 892-902. https://doi.org/10.1002/lno.11434

Bou, M., Berge, G., Baeverfjord, G., Sigholt, T., Østbye, T., Ruyter, B. (2017). Low levels of very-long-chain n3 PUFA in Atlantic salmon (Salmo salar) diet reduce fish robustness under challenging conditions in sea cages. Journal of Nutritional Science, 6: E32. https://doi.org/10.1017/jns.2017.28

Brown, J.H., Gillooly, J.F., Allen, A.P., Savage, V.M., West, G.B. (2004). Toward a metabolic theory of ecology. Ecology 85: 1771-1789. https://doi.org/10.1890/03-9000

Byström, P. (2006). Recruitment pulses induce cannibalistic giants in Arctic char. Journal of Animal Ecology 75 : 434-444. https://doi.org/10.1111/j.1365-2656.2006.01064.x

Carpenter, S.R., Kitchell, J.F., Hodgson, J.R. (1985). Fish predation and herbivory can regulate lake ecosystems. BioScience 35: 634-639. https://doi.org/10.2307/1309989

Carpenter, S.R., Cole, J.J., Hodgson, J.R., Kitchell, J.F., Pace, M.L., Bade, D., ..., Schindler, D.E. (2001). Trophic cascades, nutrients, and lake productivity: whole lake experiments. Ecological Monographs 71, 163186. https://doi.org/10.2307/2657215

Cohen, J., Screen, J.A., Furtado, J.C., Barlow, M., Whittleston, M., Whittleston, D., .. , Overland, J. (2014). Recent Arctic amplification and extreme mid latitude weather. Nature Geoscience 7: 627-637. https://doi.org/10.1038/ngeo2234

Colombo, S.M., Rodgers, T.F.M., Diamond, M.L., Bazinet, R.P., Arts, M.T. (2020). Projected declines in global DHA availability for human consumption as a results of global warming. Ambio 49: 865-880. https://doi.org/10.1007/s13280-019-01234-6 
Cott, P.A, Schein, A., Hanna, B.W., Johnston, T.A., MacDonald, D.D., Gunn, J.M. (2015). Implications of linear developments on northern fishes. Environmental Reviews 23: 177-190. https://doi.org/10.1139/er-2014-0075

Creed, I.F., Bergström, A.-K.,Trick, C.G., Grimm, N.B., Hessen, D.O., Karlsson, J., .., Weyhenmeyer, G.A. (2018). Global change-driven effects on dissolved organic matter composition: Implications for food webs of northern lakes. Global Change Biology 24: 3692-3714. https://doi.org/10.1111/gcb.14129

Dai, A., Song, M., (2020). Little influence of Arctic amplification on mid-latitude climate. Nature Climate Change 10: 231-237. https://doi.org/10.1038/s41558-020-0694-3

Denisov, D., Terentjev, P., Valkova, S., Kudryavtzeva, L. (2020). Small lakes ecosystems under the impact of $\begin{array}{llllll}\text { non-ferrous } & \text { metallurgy } & \text { (Russia, } & \text { Murmansk } & \text { Region). } & \text { Environments }\end{array}$ https://doi.org/10.3390/environments7040029.

Elton, C.S. (1927). Animal ecology. Sidgwick \& Jackson, London. https://doi.org/10.5962/bhl.title.7435

Gaston, K.J. (2000). Global patterns in biodiversity. Nature 405: 220-227. https://doi.org/10.1038/35012228

Geay, F., Tinti, E., Mellery, J., Michaux, C., Larondelle, Y., Perpete, E., Kestemont, P. (2016). Cloning and functional characterization of $\Delta 6$ fatty acid desaturase (FADS2) in Eurasian perch (Perca fluviatilis). Comparative Biochemistry and Physiology Part B 191: 112-125. https://doi.org/10.1016/j.cbpb.2015.10.004

Gladyshev, M.I., Semenchenko, V.P., Dubovskaya, O.P., Fefilova, E.B., Makhutova, O.N., Buseva, Z.F., ... , Kononova, O.N. (2011). Effect of temperature on contents of essential highly unsaturated fatty acids in freshwater zooplankton. Limnologica 41: 339-347. https://doi.org/10.1016/j.limno.2011.03.001

Grosbois, G., Mariash, H., Schneider, T., Rautio, M. (2017). Under-ice availability of phytoplankton lipids is key to freshwater zooplankton winter survival. Scientific Reports 7: 11543. https://doi.org/10.1038/s41598-01710956-0

Gyllström, M., Hanson, L.-A., Jeppesen, E., García-Criado, F., Gross, E., Kairesalo, T., .., , Moss, B. (2005). The role of climate in shaping zooplankton communities of shallow lakes. Limnology and Oceanography 50: 2008-2021. https://doi.org/10.4319/lo.2005.50.6.2008 
613 Hairston, N.G., Smith, F.E., Slobodkin, L.B. (1960). Community structure, population control and competition.

615 Hansson, L.-A., Annadotter, H., Bergman, E., Hamrin, S.F., Jeppesen, E., Kairesalo, T., Strand, J. (1998). 616 Biomanipulation as an application of food-chain theory: constraints, synthesis, and recommendations for 617 temperate lakes. Ecosystems 1: 558-574. https://doi.org/10.1007/s100219900051

618 Hansson, L.-A., Nicolle, A., Granéli, W., Hallgren, Kritzberg, E., Persson, A., ... , Brönmark, C. (2013). Foodchain length alters community responses to global change in aquatic systems. Nature Climate Change 3: 228233. https://doi.org/10.1038/nclimate1689

Hanson, J.M., Leggett, W.C. (1982). Empirical prediction of fish biomass and yield. Canadian Journal of

Hayden, B., Harrod, C., Thomas, S. M., Eloranta, A. P., Myllykangas, J.-P., Siwertsson, A., Præbel, K., Knudsen R., Amundsen, P.-A., Kahilainen, K. K. (2019). From clear lakes to murky waters-tracing the functional response of high-latitude lake communities to concurrent 'greening' and 'browning'. Ecology Letters 22: 807-816. https://doi.org/10.1111/ele.13238

Hayden, B., Myllykangas, J.-P., Rolls, R., Kahilainen, K.K. (2017). Climate and productivity shape fish and invertebrate community structure in subarctic lakes. Freshwater Biology 62: 990-1003. https://doi.org/10.1111/fwb.12919 of benthic and pelagic resources to maintenance, growth and reproduction in a generalist salmonid fish. Journal of Animal Ecology 83: 1501-1512. https://doi.org/10.1111/1365-2656.12233

Hayden, B., Harrod, C., Kahilainen, K.K. (2014b). Lake morphometry and resource polymorphism determine niche segregation between cool-and cold-water-adapted fish. Ecology, 95: 538-552. https://doi.org/10.1890/13$\underline{0264.1}$ pelagic and benthic microalgae. Journal of Phycology 35: 403-424. https://doi.org/10.1046/j.1529- 
Hillebrand, H. (2004). On the generality of latitudinal diversity gradient. The American Naturalist 163: 192-211. https://doi.org/10.1086/381004

Hiltunen, M., Taipale, S.J., Strandberg, U., Kahilainen, K.K., Kankaala, P. (2016). High intraspecific variation in fatty acids of Eudiaptomus in boreal and subarctic lakes. Journal of Plankton Research 38: 468-477. https://doi.org/10.1093/plankt/fbw008

Hixson, S.M., Arts, M.T. (2016). Climate warming is predicted to reduce omega-3, long-chain, polyunsaturated fatty acid production in phytoplankton. Global Change Biology 22: 2744-2755. https://doi.org/10.1111/gcb.13295

Huntington, H.P., Boyle, M., Flowers, G.E., Weatherly, J.W., Hamilton, L.C., Hinzman, L., ... , Overpeck, J. (2007). The influence of human activity in the Arctic on climate and climate impacts. Climatic Change, 82: 7792. https://doi.org/10.1007/s10584-006-9162-y

Ishikawa, A., Kabeya, N., Ikeya, K., Kakioka, R., Cech, J.N., Osada, N., ..., Kitano, J. (2019). A key metabolic gene for recurrent freshwater colonization and radiation in fishes. Science 364: 886-889. https://doi.org/10.1126/science.aau5656

IPCC (2015). Climate Change 2014: Synthesis report. Contribution of working groups I, II and III to the fifth assessment report of the intergovernmental panel on climate change. Geneva, Switzerland.

Jensen, H., Kahilainen, K.K., Vinni, M., Gjelland, K.Ø., Malinen, T., Harrod, C., ..., Amundsen, P.-A. (2015). Food consumption rates of piscivorous brown trout (Salmo trutta) foraging on contrasting coregonid prey. Fisheries Management and Ecology 22: 295-306. https://doi.org/10.1111/fme.12126

Jeppesen, E., Jensen, J., Søndergaard, M., Lauridsen, T., Landkildehus, F. (2000). Trophic structure, species richness and biodiversity in Danish lakes: Changes along a phosphorus gradient. Freshwater Biology 45: 201218. https://doi.org/10.1046/j.1365-2427.2000.00675.x

Jeppesen, E., Meerhoff, M., Holmgren, K., Conzález-Bergonzoni, I., Teixeira-de Mello, F., Declerck, S.A.J., ... , Lazzaro, X. (2010). Impacts of climate warming on lake fish community structure and potential effects on ecosystem function. Hydrobiologia 646: 73-90. https://doi.org/10.1007/s10750-010-0171-5 
664

665

666

667

668

669

670

671

672

673

674

675

676

677

678

679

680

681

682

683

684

685

686

687

688

Jeppesen, E., Mehner, T., Winfield, I.J., Kangur, K., Sarvala, J., Gerdeaux, D., ..., Meerhoff, M. (2012). Impacts of climate warming on the long-term dynamics of key fish species in 24 European lakes. Hydrobiologia 694: 139. https://doi.org/10.1007/s10750-012-1182-1

Jussila, M., Liljaniemi, P., Karvonen, L., Johansson, M. (2014). Water protection in regeneration cutting and site preparation areas. Guidelines and practices in the field. Centre for Economic Development, Transport, and the Environment for Lapland. Report 72: 1-36.

Jørgensen, E. H., Johansen, S. J. S., Jobling, M. (1997). Seasonal patterns of growth, lipid deposition and lipid depletion in anadromous Arctic charr. Journal of Fish Biology 51: 312-326. https://doi.org/10.1111/j.10958649.1997.tb01668.x

Kabeya, N., Fonseca, M.M., Ferrier, D.E.K., Navarro, J.C., Bay, L.K., Francis, D.S., Tocher, D.R., Castro, F.C., Monroig, Ó. (2018). Genes for de novo biosynthesis of omega-3 polyunsaturated fatty acids are widespread in animals. Science Advances 4: eaar6849. https://doi.org/10.1126/sciadv.aar6849

Kahilainen, K., Lehtonen H. (2003). Piscivory and prey selection of four predator species in a whitefish dominated subarctic lake. Journal of Fish Biology 63: 659-672. https://doi.org/10.1046/j.10958649.2003.00179.x

Kahilainen, K.K., Østbye, K., Harrod, C., Shikano, T., Malinen, T., Merilä, J. (2011). Species introduction promotes hybridization and introgression in Coregonus: is there sign of selection against hybrids? Molecular Ecology 20: 3838-3855. https://doi.org/10.1111/j.1365-294X.2011.05209.x

Kahilainen, K.K., Thomas, S.M., Nystedt, E.K.M., Keva, O., Malinen, T., Hayden, B. (2017). Ecomorphological divergence drives differential mercury bioaccumulation of polymorphic European whitefish (Coregonus lavaretus) populations of subarctic lakes. Science of the Total Environment 599-600: 1768-1778. https://doi.org/10.1016/j.scitotenv.2017.05.099

Kahilainen, K.K., Thomas, S.M., Harrod, C., Hayden, B., Eloranta, A.P. (2019). Trophic ecology of piscivorous Arctic charr (Salvelinus alpinus (L.)) in subarctic lakes with contrasting food-web structures. Hydrobiologia 840: 227-243. https://doi.org/10.1007/s10750-018-3845-z 
Keva, O., Tang, P., Käkelä, R., Hayden, B., Harrod, C., Kahilainen, K.K. (2019). Seasonal changes in European whitefish muscle and invertebrate prey fatty acid composition in a subarctic lake. Freshwater Biology 64: 19081920. https://doi.org/10.1111/fwb.13381

Kosten, S., Huszar, V.L.M., Bécares, E., Costa, L.S., van Don, E., Hansson, L.-A., ..., Scheffer, M. (2012). Warmer climates boost cyanobacterial dominance in shallow lakes. Global Change Biology 18: 118-126. https://doi.org/10.1111/j.1365-2486.2011.02488.x

Kultti, S., Mikkola, K., Virtanen, T., Timonen, M., Eronen, M. (2006). Past changes in the Scots pine forest line and climate in Finnish Lapland: A study based on megafossils, lake sediments, and GIS-based vegetation and climate data. The Holocene, 16: 381-391. https://doi.org/10.1191/0959683606hl934rp

Lappalainen, J., Tarkan, A.S., Harrod, C. (2008). A meta-analysis of latitudinal variations in life-history traits of roach, Rutilus rutilus, over its geographical range: linear or non-linear relationships? Freshwater Biology, 53: 1491-1501. https://doi.org/10.1111/j.1365-2427.2008.01977.x

Laske, S. Amundsen, P.-A., Christoffersen, K.S., Erkinaro, J. ,Guðbergsson, G., Hayden, B., ... , Zimmerman, C.E. (2020). Circumpolar patterns of Arctic freshwater fish biodiversity: A baseline for monitoring. Freshwater Biology, https://doi.org/10.1111/fwb.13405

Lau D.C.P., Christoffersen, K.S., Erkinaro, J., Hayden, B., Heino, J., Hellsten, S., .. , Goedkoop, W. (2020). Multitrophic biodiversity patterns and environmental descriptors of sub-Arctic lakes in northern Europe. Freshwater Biology 00: 1-19. https://doi.org/10.1111/fwb.13477

Leppä, M., Hämäläinen, H., Karjalainen, J. (2003). The response of benthic macroinvertebrates to whole-lake biomanipulation. Hydrobiologia 498: 97-105. https://doi.org/10.1023/A:1026224923481

Makhutova, O.N., Shulepina, S.P., Sharapova, T.A., Dubovskaya, O.P., Sushchik, N.N., Baturina, M.A., ... Gladyshev, M.I. (2016). Content of polyunsaturated fatty acids essential for fish nutrition in zoobenthos species. Freshwater Science 35: 1222-1234. https://doi.org/10.1086/688760

Malinen, T., Tuomaala, A., Lehtonen, H., Kahilainen, K.K. (2014). Hydroacoustic assessment of mono- and polymorphic Coregonus density and biomass in subarctic lakes. Ecology of Freshwater Fish, 23: 424-437. https://doi.org/10.1111/eff.12096 
McCauley, E. (1984). The estimation of the abundance and biomass of zooplankton samples. In: A manual on methods for the assessment of secondary productivity in freshwaters, Downing, L.A., Rigler, F.H. Blackwell, Oxford, 228-265.

McCauley, D.J., Gellner, C., Martinez, N.D., Williams, R.J., Sandin, S.A., Micheli, F., .. , McCann, K.S. (2018). On the prevalence and dynamics of inverted trophic pyramids and otherwise top-heavy communities. Ecology Letters 439-454. https://doi.org/10.1111/ele.12900

Menden-Deuer, S., Lessard, E.J. (2000). Carbon to volume relationships for dinoflagellates, diatoms, and other protist plankton. Limnology and Oceanography 45: 569-579. https://doi.org/10.4319/1o.2000.45.3.0569

Müller-Navarra, D.C., Brett, M.T., Liston, A.M., Goldman, C.R. (2000). A highly unsaturated fatty acid predicts carbon transfer between primary producers and consumers. Nature 403: 74-77. https://doi.org/10.1038/47469

Müller-Navarra, D.C., Brett, M.T., Park, S., Chandra, S., Ballantyne, A.P., Zorita, E., Goldman, C.R. (2004). Unsaturated fatty acid content in seston and tropho-dynamic coupling in lakes. Nature 427: 69-72. https://doi.org/10.1038/nature02210

Nieminen, M., Koskinen, M., Sarkkola, S., Laurén, A., Kaila, A., Kiikkilä, O., Nieminen, T.M., Ukonmaanaho, L. (2015). Dissolved organic carbon export from harvested peatland forests with differing site characteristics. Water, Air \& Soil Pollution 226: 181. https://doi.org/10.1007/s11270-015-2444-0

Nurminen, L., Héllen, N., Olin, M., Tiainen, J., Vinni, M., Grönroos, M., Estlander, S., Horppila, J., Rask, M., Lehtonen, H. (2018). Fishing-induced changes in predation pressure by perch (Perca fluviatilis) regulate littoral benthic macroinvertebrate biomass, density, and community structure. Aquatic Ecology 52: 1-16. https://doi.org/10.1007/s10452-017-9641-4

Nürnberg, G. (1996). Trophic state of clear and colored, soft- and hardwater lakes with special consideration of nutrients, anoxia, phytoplankton and fish. Lake and Reservoir Management 12: 432-447. https://doi.org/10.1080/07438149609354283

Olin, M., Tiainen, J., Rask, M., Vinni, M., Nyberg, K., Lehtonen, H. (2017). Effects of non-selective and sizeselective fishing on perch populations in a small lake. Boreal Environment Research 22: 137-155. 
Oksanen, L., Fretwell, S.D., Arruda, J., Niemelä, P. (1981). Exploitation ecosystems in gradients of primary production. American Naturalist 118: 240-260. https://doi.org/10.1086/283817

Paine, R.T. (1980). Food webs: Linkage, interaction strength and community infrastructure. Journal of Animal Ecology 49: 667-685. https://doi.org/110.2307/4220

Post, D.M., Pace, M.L., Hairston Jr., N.G. (2000). Ecosystem size determines food-chain length in lakes. Nature 405: 1047-1049. https://doi.org/10.1038/35016565

Przytulska, A., Bartosiewicz, M., Vincent, W.F. (2017). Increased risk of cyanobacterial blooms in northern highlatitude lakes through climate warming and phosphorus enrichment. Freshwater Biology, 62: 1986-1996. https://doi.org/10.1111/fwb.13043

Rask, M., Malinen, T., Olin, M., Peltonen, H., Ruuhijärvi, J., Vesala, S., Hietala, J. (2020). Responses of the fish community in a eutrophicated lake to long-term food web management assessed by multiple sampling methods. Hydrobiologia, in press. https://doi.org/10.1007/s10750-020-04243-9.

R Core Team (2017). R: A language and environment for statistical computing. R Foundation for Statistical Computing, Vienna, Austria. https://www.R-project.org/.

Rolls, R.J., Hayden, B., Kahilainen, K.K. (2017). Conceptualising the interactive effects of climate change and biological invasions on subarctic freshwater fish. Ecology and Evolution 7: 4109-4128. https://doi.org/10.1002/ece3.2982

Samarsin, P., Minns, C.K., Shuter, B.J., Tonn, W.M., Rennie, M.D. (2015). Fish diversity and biomass in northern Canadian lakes: northern lakes are more diverse and have greater biomass than expected based on species-energy theory. Journal of Canadian Fisheries and Aquatic Sciences 72: 226-237. https://doi.org/10.1139/cjfas-20140104

Senar, O.E., Creed, I.F., Strandberg, U., Arts, M.T. (2019). Browning reduces the availability but not the transfer of essential fatty acids in temperate lakes. Freshwater Biology 64: 2107-2119. https://doi.org/10.1111/fwb.13399 
Scharnweber K., Chaguaceda, F., Dalman, E., Tranvik, L., Eklöv, P. (2020). The emergence of fatty acidsAquatic insects as vectors along a productivity gradient. Freshwater Biology 65: 567-578. https://doi.org/10.1111/fwb.13454

Scheffer, M., Carpenter, S.R. (2003). Catastrophic regime shifts in ecosystems: linking theory to observation. Trends in Ecology \& Evolution 18: 648-656. https://doi.org/10.1016/j.tree.2003.09.002

Schindler, D.W. \& Smol, J.P. (2006). Cumulative effects of climate warming and other human activities on freshwaters of Arctic and subarctic North America. Ambio 35: 160-168. https://doi.org/10.1579/00447447(2006)35[160:CEOCWA]2.0.CO;2Smit, H., van Heel E.D., Wiersma S. (1993). Biovolume as a tool in biomass determination of Oligochaeta and Chironomidae. Freshwater Biology 29: 37-46. https://doi.org/10.1111/j.1365-2427.1993.tb00742.x

Strandberg, U., Hiltunen, M., Jelkänen, E., Taipale, S.J., Kainz, M.J., Brett, M.T., Kankaala, P. (2015). Selective transfer of polyunsaturated fatty acids from phytoplankton to planktivorous fish in large boreal lakes. Science of the Total Environment 536: 858-865. https://doi.org/10.1016/j.scitotenv.2015.07.010

Taipale, S.J., Vuorio, K., Strandberg, U., Kahilainen, K.K., Järvinen, M., Hiltunen, M., Peltomaa, E., Kankaala, P. (2016). Lake eutrophication and brownification downgrade availability and transfer of essential fatty acids for human consumption. Environment International 96: 156-166. https://doi.org/10.1016/j.envint.2016.08.018

Taipale, S.J., Peltomaa, E.J., Salmi, P. (2020). Variation in $\omega-3$ and $\omega-6$ polyunsaturated fatty acids produced by different phytoplankton taxa at early and late growth phase. Biomolecules 10: 559. https://doi.org/10.3390/biom10040559

Twining, C.W., Brenna, J.T., Hairston, N.G., Flecker, A.S. (2016). Highly unsaturated fatty acids in nature: what we know and what we need to learn. Oikos 125: 749-760. https://doi.org/10.1111/oik.02910

Takimoto, G., Post, D.M., Spiller, D.A., Holt, R.D. (2012). Effects of productivity, disturbance, and ecosystem size on food-chain length: insights from a metacommunity model of intraguild predation. Ecological Research 27: 481-493. https://doi.org/10.1007/s11284-012-0943-7

Takimoto, G., Post, D.M. (2013). Environmental determinants of food-chain length: A meta-analysis. Ecological Research 28: 675-681. https://doi.org/10.1111/1365-2656.12326 
Thomas, S.M., Crowther, T.W. (2015). Predicting rates of isotopic turnover across the animal kingdom: a synthesis of existing data. Journal of Animal Ecology 84, 861-870.

Thomas, S.M., Harrod, C., Hayden. B., Malinen, T., Kahilainen, K.K. (2017). Ecological speciation in a generalist consumer expands the trophic niche of a dominant predator. Scientific Reports 7: 8765. https://doi.org/10.1038/s41598-017-08263-9

Thomas, S.M., Kainz, M., Amundsen, P.-A., Hayden, B., Taipale, S.J., Kahilainen, K.K. (2019). Resource polymorphism in European whitefish: Analysis of fatty acid profiles provides more detailed evidence than traditional methods alone. PloSOne 14: e0221338. https://doi.org/10.1371/journal.pone.0221338

Utermöhl, H. (1958). Zur Vervollkommnung der quantitativen Phytoplankton-Methodik. Verhandlungen der Internationalen Vereinigung fur Theoretische und Angewandte Limnologie 9: 1-38.

Vadeboncoeur, Y., Jeppesen, E., Vander Zanden, M.J., Schierup, H.-H. Cristoffersen, K., Lodge, D. M. (2003). From Greenland to green lakes: Cultural eutrophication and the loss of benthic pathways in lakes. Limnology and Oceanography 48: 1408-1418. https://doi.org/10.4319/lo.2003.48.4.1408

Vadeboncoeur, Y., Åeterson, G., Vander Zanden, M.J., Kalff, J. (2008). Benthic algal production across lake size gradients: interactions among morphometry, nutrients and light. Ecology 89: 2542-2552. https://doi.org/10.1890/07-1058.1

Vadeboncoeur, Y., Power, M. (2017). Attached algae: the cryptic base of inverted trophic pyramids in freshwaters. Annual Review of Ecology, Evolution, and Systematics 48: 255-279. https://doi.org/10.1146/annurev-ecolsys-121415-032340

Vesterinen, J., Devlin, S.P., Syväranta, J., Jones, R.I. (2016). Accounting for littoral primary production by periphyton shifts a highly humic boreal lake towards net autotrophy. Freshwater Biology 61: 256-276.

\section{https://doi.org/10.1111/fwb.12700}

Vesterinen, J., Keva, O., Kahilainen, K.K., Strandberg, U., Hiltunen, M., Kankaala, P., Taipale, S.J. (2020). Nutritional quality of littoral macroinvertebrates and pelagic zooplankton in subarctic lakes. Limnology and Oceanography. Early view, https://doi.org/10.1002//no.11563 
814 Ward, C.L., McCann, K.S. (2017). A mechanistic theory for aquatic food chain length. Nature Communications 815 8: 2028. https://doi.org/10.1038/s41467-017-02157-0

816 Wickham, H. (2016). ggplot2: Elegant Graphics for Data Analysis. Springer-Verlag New York.

817 Winfield, I.J., Nelson, J.S. (1991). Cyprinid fishes: Systematics, biology and exploitation Cambridge University 818 Press, Cambridge.

819 Yeşilayer, N., Kaymak, I.E. (2020). Effect of partial replacement of dietary fish meal by soybean meal with 820 betaine attractant supplementation on growth performance and fatty acid profiles of juvenile rainbow trout 821 (Oncorhynchus mykiss). Aquaculture Research 51: 1533-1541. https://doi.org/10.1111/are.14501

822 Zubova, E.M., Kashulin, N.A., Dauvalter, V.A., Denisov, D.B., Valkova, S.A., Vandysh, O.I., ..., Cherepanov, 823 A.A. (2020). Long-term environmental monitoring in an Arctic lake polluted by metals under climate change. 824 Environments 7: 35. https://doi.org/10.3390/environments7050034 
Fig. 1. Map of the study region (A) in northern Fennoscandia and boxplot figures of the basic lake chemistry (B-D) and physics (E-F) of the sampled lakes. The study lakes are marked with grey shade shapes (A) or boxes (B-D) indicating different lake types $($ light grey $=$ ultraoligotrophic, grey $=$ oligotrophic, dark grey $=$ mesotrophic, black $=$ eutrophic) . Abbreviations in $\mathrm{x}$-axes labels are named as following: TotP=total phosphorous (B), TotN = total nitrogen (C), DOC = dissolved organic carbon (D), Temp = average air temperature in June-September 1981-2010 (E), CompD = compensation depth i.e. water depth where $1 \%$ surface light is left (F).

Fig. 2. Community structure (A), biomass (B) and computed community quality (FA content, C) across different lake types (x-axis). Food web community compartments: phytoplankton (1), zooplankton (2), littoral benthos (3), profundal benthos (4), invertivorous fish (5) and piscivorous fish (6) are presented in different columns. The coloured bars indicate average taxa values of different lake types as following: normalized relative community composition (A: biomass \%), lake type average biomass (B1-B2: $\mathrm{mg} \mathrm{dw} \mathrm{m}^{-3}$, B3-B6: $\mathrm{kg} \mathrm{dw} \mathrm{ha}^{-1}$ ) and lake type average community EPA and DHA content (C: $\mathrm{mg}$ $\mathrm{FA} \mathrm{g}^{-1} \mathrm{dw}$ ). Lake specific community bulk FA content is derived from the FA analysed bulk sample (C2: zooplankton) and calculated for other food web community compartments (C1, C3-C6) from taxa specific biomass contribution and fatty acid content. Whiskers on top of the lake type average (B and C rows) represents + SD.

Fig. 3. Linear regression models showing A-B: Community biomass $\left(\mathrm{kg} \mathrm{dw} \mathrm{ha}^{-1}\right)$ and quality $\left(\mathrm{mg} E P A+D H A ~ \mathrm{~g}^{-1} \mathrm{dw}\right)$ against climate-productivity index $(\mathrm{CPi})$ and $\mathrm{C}$ : $\mathrm{EPA}+\mathrm{DHA}$ areal content $\left(\mathrm{kg} \mathrm{EPA}+\mathrm{DHA} \mathrm{ha}{ }^{-1}\right)$ against total food web biomass $\left(\mathrm{kg} \mathrm{dw} \mathrm{ha}^{-1}\right)$. Food web community compartments: phytoplankton (1), zooplankton (2), littoral benthos (3), profundal benthos (4), invertivorous fish (5) and piscivorous fish (6) are presented in different columns. The grey shaded shapes indicate different lake trophy corresponding to Fig. 1: light grey square $=$ ultraoligotrophic, grey dot $=$ oligotrophic, dark grey triangle $=$ mesotrophic, black diamond $=$ eutrophic. Linear regressions fits (bolded line), 95\% confidence limit (grey shaded areas) and adjusted coefficient of determination $\left(\mathrm{r}^{2}\right)$ are presented in the figures if the model was statistically significant $(\mathrm{p}<0.05)$. Linear regression equations, $F$ statistics, adjusted $\mathrm{r}^{2}$ and $\mathrm{p}$ values are presented for each model in Table S6.

Fig. 4. Relative biomass (A) and FA stock (B) pyramids by food web compartments for the lake types. The pyramid steps represent lake type averages of relative biomass or EPA+DHA areal content and are ordered with trophic level from bottomup order: 1) phytoplankton, 2) invertebrates, 3) invertivorous fish and 4) piscivorous fish. The second trophic level (invertebrates) are divided among profundal benthos, littoral benthos and zooplankton with patterns: transparent, spots, stripes respectively. Different lake types, ultraoligotrophic, oligotrophic, mesotrophic and eutrophic respectively, are separated into different columns delineated with dashed lines and additionally with light grey, grey, dark grey, black respectively. The lake specific data is presented at Fig. S2. Abbreviations in legend are BMI = benthic macroinvertebrates and ZPL = zooplankton. 